\title{
A Duty to Give Reasons in the Security Council Making Voting Transparent
}

\author{
Daniel Moeckli \\ Assistant Professor of Public International Law and Constitutional Law, \\ University of Zurich \\ daniel.moeckli@uzh.ch \\ Raffael N. Fasel \\ Ph.D. in Law candidate, Sidney Sussex College, University of Cambridge \\ rnf22@cam.ac.uk
}

\begin{abstract}
In recent years, the UN Security Council has repeatedly come under criticism for its inaction in the face of serious violations of international law. As a means to prevent further deadlocks, this article advocates the introduction of a duty to explain votes cast in the Council. In certain situations, such a duty to give reasons already exists today, although it is not implemented. We propose to extend this duty to all votes in the Security Council and to codify it in its Provisional Rules of Procedure. A comprehensive duty to give reasons has three major virtues: it increases the quality of Council decisions, it enhances legal certainty, and it improves the accountability of the Council and of its members. As opposed to structural reforms, our proposal does not necessitate amending the UN Charter and thus does not depend on the consent of the Council's permanent members.
\end{abstract}

\section{Keywords}

Provisional Rules of Procedure - duty to give reasons - discourse theory - transparencySecurity Council reform

* Earlier versions of this article were presented at the Institute for Public International Law of the University of Zurich in March 2014 and at the Faculty of Law of the University of Basel in May 2014. We would like to thank the participants of the respective events for their thoughtful comments.

(C) DANIEL MOECKLI AND RAFFAEL N. FASEL, 2017 DOI 10.1163/15723747-2017001

This is an open access article distributed under the terms of the Creative Commons Attribution-

Noncommercial 4.0 Unported (CC-BY-NC 4.0) License. http://creativecommons.org/licenses/by-nc/4,0/2623 12:20:01PM 


\section{Introduction}

On 18 December 2014 the UN General Assembly called on the Security Council to consider referring the situation in the Democratic People's Republic of Korea to the International Criminal Court ('ICC'). ${ }^{1}$ The resolution, adopted by a vote of 116 to 20 with 53 abstentions, followed a UN Commission of Inquiry report that detailed systematic, widespread and gross violations of human rights in North Korea and concluded that, in many instances, these violations amounted to crimes against humanity. ${ }^{2}$ It is, however, unlikely that a resolution referring the situation in North Korea to the ICC would even be proposed in the Security Council since China has made it clear that it will veto any such proposal. $^{3}$

This and similar instances of inaction by the Security Council in the face of serious violations of international law, including with regard to the situations in Syria and Israel/Palestine, have reignited criticism of the Council. However, it would be naïve to expect that deadlocks of the Council could be addressed through reform of membership of the Council or the veto power. Any such reform would require an amendment of the UN Charter, which can be blocked by the non-ratification of one of the Council's five permanent members ('P 5 '). ${ }^{4}$

In this article, we explain how the risk of such deadlocks of the Security Council could be minimized through a change of its procedure, rather than its structure. We argue that enhancing the transparency of the Council's working methods would help it better perform its tasks. More specifically, we suggest the introduction of a duty to give reasons for votes cast in the Security Council. As opposed to structural reforms, our proposal does not depend on the consent of the $\mathrm{P}_{5}$ : it can be implemented through an amendment of the Council's Provisional Rules of Procedure ('PRoP'), which only requires the affirmative vote of nine members. ${ }^{5}$

1 UN General Assembly, Resolution 69/188 (18 December 2014), UN Doc. A/REs/69/188.

2 Human Rights Council, Report of the Commission of Inquiry on Human Rights in the Democratic People's Republic of Korea on its Twenty-Fifth Session, (7 February 2014), UN Doc. A/HRc/25/63.

3 On 22 December 2014, for example, the Chinese representative in the Security Councilafter having unsuccessfully opposed that the situation be placed on the Council's provisional agenda-declared: "We oppose the adoption of any outcome document by the Council on the human rights situation in the Democratic People's Republic of Korea.” Un Security Council, $69^{\text {th }}$ Session, $7353^{\text {rd }}$ meeting (22 December 2014), UN Doc. s/PV.7353, p. 16.

4 UN Charter, Art 108.

5 See infra Section 4.2.1. 
In Section 1, we analyse the working methods of the Security Council and its subsidiary bodies and highlight the lack of transparency, in particular the absence of a duty to give reasons for decisions or votes. Section 2 discusses the legal limits that are applicable to acts (or omissions) of the Security Council as a collective body as well as the voting behaviour of its members. We argue that the Council does not operate in a legal vacuum and that compliance with the legal limits imposed on it and its members can be reviewed in various ways. However, a meaningful legal review of the Council's acts and its members' votes is only possible if the reviewing body knows the motives behind them. In Section 3, we show that, in certain situations, there is already today, de lege lata, an obligation incumbent on the Security Council to give reasons for its decisions and, respectively, on its members to explain their votes. In Section 4, we sketch out a proposal to introduce, de lege ferenda, a comprehensive duty to explain in a public meeting every vote cast in the Security Council. Such a duty to give reasons, we argue, has three major virtues: it increases the quality of Council decisions, it enhances legal certainty, and it improves the accountability of the Council as a whole and of its members.

\section{$1 \quad$ Lack of Transparency in Security Council Deliberations}

Today, the Security Council conducts the bulk of its business behind closed doors. As a general rule, reasons are given neither for the votes cast in the Council by its members nor for the Council's decisions themselves (Section 1.1). The working methods of the subsidiary bodies established by the Security Council are even more obscure. Often they do not even communicate their decisions, let alone the reasons for them (Section 1.2).

\subsection{Working Methods of the Security Council}

In the first decades of its existence, the Security Council met only rarely and did not decide much. On average it adopted fourteen resolutions a year, ${ }^{6}$ most of which did not attract much attention. ${ }^{7}$ With the end of the Cold War, this changed dramatically. Not only does the Council now meet on an almost daily basis and pass significantly more resolutions: on average 62 a year. ${ }^{8}$ It has also

6 Michael C. Wood, 'Security Council Working Methods and Procedure: Recent Developments' (1996) 45 International and Comparative Law Quarterly p. 151.

7 Michael C. Wood, 'The Interpretation of Security Council Resolutions' (1998) 2 Max Planck Yearbook of United Nations Law p. 74.

8 See infra Figure 1. 
expanded its scope of activity in qualitative terms: Beyond the executive functions for which it was originally designed, the Security Council today regularly acts as an administrative body, directly affecting important interests of individuals and entities other than states, and even performs certain legislative tasks. ${ }^{9}$ As a consequence, its resolutions have become more complex and significant.

The working methods of the Security Council have in no way kept pace with these developments. They are still based on the PRoP, which were discussed at the Council's very first meeting of 17 January 1946 and adopted on 9 April $1946 .{ }^{10}$ As their title indicates, these were originally merely meant to serve as an interim solution but became permanent as the Council members (especially the P5) preferred to retain flexibility rather than to settle on a fixed, detailed set of procedures. ${ }^{11}$ Compared with the rules of procedure of other international organs, they are rudimentary. ${ }^{12}$ The PRoP contain only few, very basic rules on decision-making. In particular, they fail to provide for a standard procedure or an institutional mechanism to ensure that resolutions are well drafted..$^{13}$

How does a resolution of the Security Council come about? Normally, a member of the Security Council (the so-called 'sponsor' of the resolution) most often one of the $\mathrm{P} 5$ - prepares a first draft, which is then discussed with the delegations of some friendly states (which may or may not be Council members). This may be followed by informal consultations with the other members of the Council. ${ }^{14}$ In most cases, however, only some select Council memberstypically the other permanent members-are consulted. ${ }^{15}$ As the representative of South Africa has complained, "resolutions and decisions of the Council are often drafted in small groups and presented as faits accomplis to elected

See e.g. Ian Johnstone, 'Legislation and Adjudication in the UN Security Council: Bringing Down the Deliberative Deficit' (2008) 102 American Journal of International Law p. 275; Paul C. Szasz, 'The Security Council Starts Legislating' (2002) 96 American Journal of International Law p. 901; Stefan Talmon, 'The Security Council as World Legislature' (2005) 99 American Journal of International Law p. 175. (Oxford University Press, Oxford, 2014) pp. 9-12 for a detailed account.

11 Pascale Baeriswyl, 'Revolution durch die Hintertür: Moderne Arbeitsmethoden für einen wirksameren UN-Sicherheitsrat' (2013) 5 Vereinte Nationen p. 197; Helmut Volger, 'Mehr Transparenz und mehr Beteiligung: Die informelle Reform der Arbeitsmethoden des UNSicherheitsrats' (2010) 5 Vereinte Nationen p. 196.

12 Wood, supra note 6, p. 160.

13 Wood, supra note 7, p. 8 o.

14 See ibid., pp. 80-82.

15 Sievers and Daws, supra note 10, p. 396; Baeriswyl, supra note 11, p. 199. 
members."16 Finally, the text of the draft resolution is circulated as an official document of the Security Council.

The President of the Security Council then calls a formal meeting of the Security Council, which, as a rule, is public. ${ }^{17}$ In the meeting, the members vote on the draft resolution by show of hands. In addition to statements made in the general debate preceding the vote, members may also explain their vote orally either before or after the vote. ${ }^{18}$ However, they are not obliged to do so. A resolution is adopted if nine or more of the fifteen members vote for it, and if it is not vetoed by any of the $\mathrm{P} 5{ }^{19}{ }^{19}$ The text of the resolution itself does not contain any reasons. While it is sometimes possible to glean some reasons from the preamble of a resolution, most preambles only include clauses that members could not find an agreement on and that were therefore removed from the operative part of the resolution. ${ }^{20}$

This means that the reasons why a resolution has (or has not) been adopted can only be gathered from the statements and explanations given in the formal meeting. Of these meetings, verbatim records are kept, which are published ${ }^{21}$ and can be accessed on the website of the Security Council. However, the members of the Security Council only very rarely explain their votes. To the extent that explanations are given, they are mainly used to make political statements rather than to clarify meaning. ${ }^{22}$ As a consequence, only those members that were themselves involved in the drafting of a given Security Council resolution will be able to understand the full significance of the action taken. Since in most cases the drafting process is in the hands of only some of the memberstypically the $\mathrm{P}_{5}$-all the other states, the media as well as the wider public will not be aware of the motives behind a given resolution.

This problem has arguably intensified over the last few years. The explosion of the workload of the Security Council in the early 199os led to greater attention being paid to its working methods, which increasingly came to be seen as outdated. Accordingly, calls were raised for a reform of the Council's working

16 UN Security Council, $67^{\text {th }}$ Session, $6870^{\text {th }}$ meeting $(26$ November 2012$)$ UN Doc. s/PV.6870, p. 17 (emphasis added).

17 PRoP (17 January 1946), un Doc. s/96/Rev.7, Rule 48.

18 This is referred to as 'statement before/after the vote' or 'explanation of vote'. Sievers and Daws, supra note 10, pp. 357-359.

19 UN Charter, Art 27(3).

$20 \quad$ Wood, supra note 7, pp. 86-87.

$21 \quad$ PRoP Rule 54.

22 Michael P. Scharf and Joshua L. Dorosin, 'Interpreting Un Sanctions: The Rulings and Role of the Yugoslavia Sanctions Committee' (1993) 19 Brooklyn Journal of International Law p. 825 . 
methods, in particular for improvements with regard to transparency, effectiveness, accountability, and participation. ${ }^{23} \mathrm{~A}$ number of important reforms were in fact implemented over the following 20 years. The Note by the President of the Security Council on the Council's working methods of 2010 lists 73 practices and measures designed "to enhance the efficiency and transparency of the Council's work, as well as interaction and dialogue with non-Council members", which had been agreed in preceding years. ${ }^{24}$ These include, among others, regular briefings of UN member states, improved documentation of the Council's work, publication of the programme of work, increased recourse to open meetings, introduction of new meeting formats, improvements with regard to the annual report to the General Assembly, better briefing of newly elected Council members, expanded consultation and cooperation with international and regional organizations (such as in 'Informal Interactive Dialogues'), ${ }^{25}$ increased discussion and consultation with troop- and policecontributing countries and other interested states, and, finally, holding of informal 'Arria-formula' meetings with non-state actors. ${ }^{26}$

Yet these efforts to make the Council's formal procedures more transparent also had a counterproductive effect in that, combined with the rising workload, they led to a shift of decision-making to more informal settings, which Council members see as more efficient and conducive to compromise. ${ }^{27}$ During the 1990s 'informal consultations' - be it of all the members of the Security Council ('informal consultations of the whole') or of some of them

23 See for a good overview Security Council Report, Special Research Report 2007 No 3: Security Council Transparency, Legitimacy and Effectiveness: Efforts to Reform Council Working Methods 1993-2007, 18 October 2007 ('Security Council Report 2007, No 3'); Security Council Report, Update Report: Security Council Working Methods, 12 August 2008 ('Security Council Report, Update Report'); Security Council Report, Special Research Report 2010 No 1: Security Council Working Methods: A Work in Progress? 30 March 2010 ('Security Council Report 2010, No 1').

24 UN President of the Security Council, Note (26 July 2010), UN Doc. s/2010/507, para. 1. This Note further developed Note (19 July 2006), un Doc. s/2006/507; Note (19 December 2007), un Doc. s/2007/749; and Note (31 December 2008), un Doc. s/2008/847. See also Note (7 February 2006), un Doc. $\mathrm{s} / \mathbf{2 0 0 6 / 7 8}$ (including an index of Notes and Statements by the President of the Security Council relating to documentation and procedure from 1993 to 2005).

25 Sievers and Daws, supra note 10, pp. 92-94.

26 UN President of the Security Council, Note (26 July 2010), un Doc. s/2010/507, Annex.

27 Natalie Reid, Global Policy Forum, Informal Consultations, 1999, available at: <https:// www.globalpolicy.org/security-council/32941.html>. 
(notably the P5) ${ }^{28}$ - became the preferred forum for carrying out the bulk of the Council's work. ${ }^{29}$

As opposed to the Council's formal meetings, informal consultations are not public, no official records are kept and non-members of the Council cannot

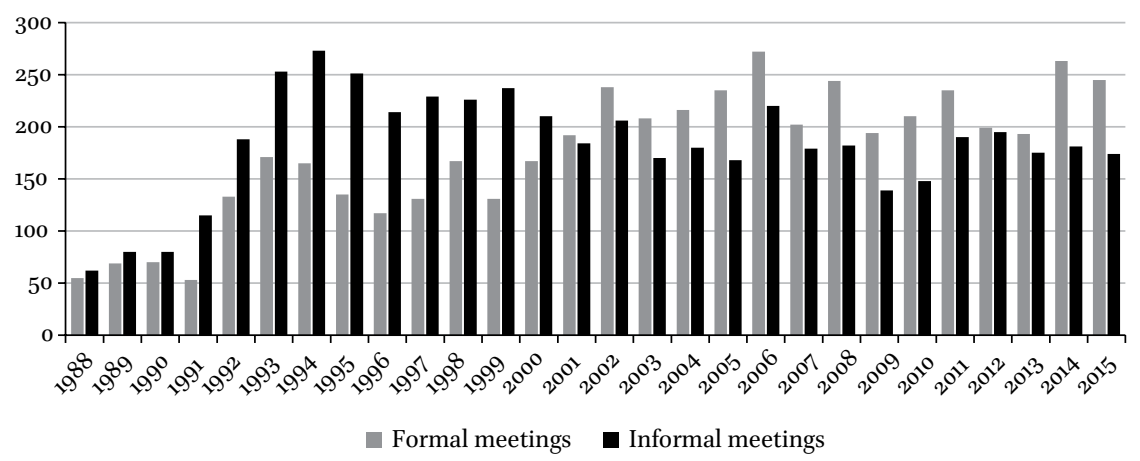

FIGURE 1 Number of formal and informal meetings of the Security Council between 1988 and $2015 .^{30}$

28 Sidney Bailey and Sam Daws, The Procedure of the UN Security Council ( $3^{\text {rd }}$ ed) (Oxford University Press, Oxford, 1998) p. 69.

29 See Loie Feuerle, 'Informal Consultation: A Mechanism in Security Council DecisionMaking' (1985) 18 New York University Journal of International Law and Politics p. 267; Reid, supra note 27.

30 For the period 2001-2015, the graph is based on Repertoire of the Security Council, Security Council Meetings and Consultations in 2001-2015 available at: <www.un.org/en/sc/ repertoire/data/2001-2015\%20Meetings\%20and\%2oconsultations.pdf> (for the number of informal consultations of the whole), on Highlights of Security Council Practice 2011, available at: <www.un.org/en/sc/inc/pages/pdf/highlights/2011.pdf> (for the number of Arria-formula meetings and Informal Interactive Dialogues in 2001-2007), on Highlights of Security Council Practice 2012, available at: <www.un.org/en/sc/inc/pages/pdf/ highlights/2012.pdf> (for the number of Arria-formula meetings and Informal Interactive Dialogues in 2008), on Highlights of Security Council Practice 2013, available at: $<w w w$ .un.org/en/sc/inc/pages/pdf/highlights/2013.pdf> (for the number of Arria-formula meetings and Informal Interactive Dialogues in 2009), on Highlights of Security Council Practice 2014, available at: <www.un.org/en/sc/inc/pages/pdf/highlights/2014.pdf> (for the number of Arria-formula meetings and Informal Interactive Dialogues in 2010), and on Highlights of Security Council Practice 2015, available at: <www.un.org/en/sc/inc/pages/pdf/ highlights/2015.pdf > (for the number of Arria-formula meetings and Informal Interactive Dialogues in 2011-2015). For the period 1988-2000, official Security Council data is unreliable, which is why the graph is based on Global Policy Forum, Number of Security Council Formal Meetings and Informal Consultations: 1988-2010, available at: <www.globalpolicy.org/images/ pdfs/Number_of_Security_Council_Formal_Meetings_and_Informal_Consultations.pdf >. 
attend. ${ }^{31}$ They are not provided for in the Charter or the PRoP. As the thenFrench permanent representative put it, "informal meetings are not even real Council meetings at all; they have no official existence, and are assigned no number."32 Nevertheless, almost all the important decisions of the Security Council are now agreed in advance in these informal, secret consultations. ${ }^{33}$ Informal consultations have replaced the formal Security Council meetings as the central forum for political interaction on questions relating to international peace and security.

At the same time, the formal public Security Council meetings have been reduced to pro forma affairs: they merely serve to put on record what has already been informally agreed. As opposed to informal consultations, which may run into several sessions lasting many hours, the formal meetings often do not last longer than five to ten minutes. ${ }^{34}$ In opening an official meeting, the President of the Council will typically refer to the text of a draft resolution that has been submitted, ${ }^{35}$ often noting that "the Council is meeting in accordance with the understanding reached in its prior consultations". ${ }^{36}$ The Council will then proceed to the vote. Actual discussions or debates have become very rare. As Erika de Wet has concluded, "[t]he net result is that the Security Council meets in public only to adopt resolutions already agreed upon in informal meetings, without giving any insight into the motives underpinning its decisions." ${ }^{37}$ This even holds true for resolutions of far-reaching importance such as Security Council Resolution 1373, passed after the terrorist attacks of 11 September 2001. Despite the complexity of the issues addressed in, and raised by, this resolution and despite its legislative nature, the respective meeting only lasted five minutes. ${ }^{38}$ Not a single statement was made on the draft resolution, and no Council member explained its vote. ${ }^{39}$

31 Sievers and Daws, supra note 10, p. 65. While the Secretariat takes notes of informal consultations for their own internal purposes, these are not available to others: Wood, supra note 7 , footnote 33 .

32 UN Security Council, $49^{\text {th }}$ Session, $3483^{\text {rd }}$ meeting (16 December 1994), un Doc. S/PV.3483.

33 Wood, supra note 6, pp. $155^{-156 .}$

34 Reid, supra note 27; Ian Hurd, 'Legitimacy, Power, and the Symbolic Life of the UN Security Council' (2002) 8 Global Governance pp. 42-3; Bailey and Daws, supra note 28, p. 76 .

35 See e.g. UN Security Council, $69^{\text {th }}$ Session, $7188^{\text {th }}$ meeting (29 May 2014), UN Doc. s/PV.7188.

36 See e.g. Un Security Council, $64^{\text {th }}$ Session, $6253^{\text {rd }}$ meeting (23 December 2009), un Doc. s/Pv.6253.

37 Erika de Wet, The Chapter vII Powers of the United Nations Security Council (Hart Publishing, Oxford, 2004) p. 108.

38 UN Security Council, $56^{\text {th }}$ Session, $4385^{\text {th }}$ meeting ( 28 September 2001$)$, un Doc. s/PV. 4385 .

39 Ibid. 
As 'informal consultations of the whole' have become institutionalized and - to some extent-themselves formalized, ${ }^{40}$ there has been a trend to move discussions and decision-making to smaller, even more informal settings. These may be meetings of groups of states (such as the P5, 'Groups of Friends' or 'Contact Groups' $)^{41}$ or even lower level meetings of experts. ${ }^{42}$ This trend of delegating substantive negotiations to more exclusive fora is problematic as it "produces even deeper layers of informality and confidentiality."43 Confidentiality characterizes not only the working methods of the Security Council itself but also those of its subsidiary bodies.

\subsection{Working Methods of Subsidiary Bodies}

The Security Council has established, as it is authorized to by Article 29 of the UN Charter, several subsidiary bodies whose composition mirrors its own. In many respects, the procedures of these subsidiary bodies are even more obscure than those of the Council itself. As is the case with the Council, the bulk of their work is carried out in informal consultations, which are held in private and without a record being taken.

The most important subsidiary bodies are the committees created by the Council to administer and monitor sanctions. ${ }^{44}$ As a general rule, the various sanctions committees conduct their business behind closed doors and do not publish records of their meetings. ${ }^{45}$ They only rarely give reasons for their decisions. ${ }^{46}$

For example, the meetings of the Iraq Sanctions Committee, established in 1990 by Security Council Resolution 661, were secret and minutes were only

$40 \quad$ See Sievers and Daws, supra note 10, pp. 66-67.

41 Reid, supra note 27; Bailey and Daws, supra note 28, pp. 68-73. See Teresa Whitfield, 'Groups of Friends' in David M. Malone (ed), The UN Security Council: From the Cold War to the $27^{\text {st }}$ Century (Lynne Rienner Publishers, Boulder co, 2004) p. 311.

42 Security Council Report 2007, No 3, supra note 23, p. 6; Security Council Report 2010, No 1, supra note 23, pp. 8-9.

43 Security Council Report 2010, No 1, supra note 23, p. 9.

44 There are currently 13 Security Council sanctions committees in place. For an overview, see the respective UN website: UN Security Council Sanctions Committees, Security Council Sanctions Committees: An Overview, available at: <https://www.un.org/sc/suborg/en/ sanctions/information>.

45 Jeremy Farrall, 'Should the United Nations Security Council Leave It to the Experts? The Governance and Accountability of UN Sanctions Monitoring' in Jeremy Farrall and Kim Rubenstein (eds), Sanctions, Accountability and Governance in a Globalised World (Cambridge University Press, Cambridge, 2009) p. 191, p. 194.

46 De Wet, supra note 37, p. 253. 
kept in the form of summary, not verbatim, records. ${ }^{47}$ While in the judgment of the Committee's former deputy secretary this created a more efficient, "more businesslike atmosphere", he also took the view that the Committee had taken the matter of secrecy too far, as its decisions were not communicated to all states potentially affected by them. ${ }^{48}$ In fact, the Committee was not even required to give account of its activities to the organ that had created it, the Security Council. 49

Similarly, the Yugoslavia Sanctions Committee, created in 1991, met behind closed doors and did not even record the vote of its members. ${ }^{50}$ Rather than publishing reasoned decisions, it only issued "brief conclusory communications, with the barest references to context", often making it impossible to ascertain the facts the Committee considered material. ${ }^{51}$ This led commentators to conclude that "the Committee has operated in obscurity, with its rulings and record familiar only to a handful of government officials, despite the fact that the interpretations of the Committee have a direct impact on the conduct of thousands of businesses around the world on a daily basis.".52

Also committees that administer so-called targeted sanctions, that is, sanctions that are directed against individuals and specific groups rather than states, exhibit a lack of transparency. While it may be appropriate for the deliberations on individual cases of such committees to be confidential, ${ }^{53}$ even general information about the basis for including individuals and groups on the respective sanctions lists (or removing them from these lists) is generally not publicly available. ${ }^{54}$ Between 1999 and 2005, the former Al-Qaida and Taliban Sanctions Committee, established according to Security Council Resolution

47 Paul Conlon, 'Lessons from Iraq: The Functions of the Iraq Sanctions Committee as a Source of Sanctions Implementation Authority and Practice' (1995) 35 Virginia Journal of International Law p. 655; Martti Koskenniemi, 'Le Comité des sanctions créé par la Résolution 661 (1990) du Conseil de Sécurité' (1991) 37 Annuaire français de droit international p. 123 .

48 Conlon, supra note 47 , pp. $655^{-6} 65^{6}$.

49 Ibid., p. 656; Koskenniemi, supra note 47, p. 123.

50 Scharf and Dorosin, supra note 22, p. 822.

$5^{1} \quad$ Ibid., p. 823 .

$52 \quad$ Ibid., pp. $825-826$.

53 See infra Section 4.2.5.

54 Watson Institute Targeted Sanctions Project, Strengthening Targeted Sanctions through Fair and Clear Procedures: White Paper, 30 March 2006, pp. 7, 26, 34, 36. See also Johnstone, supra note 9, p. 298 and Devika Hovell, The Power of Process: The Value of Due Process in Security Council Sanctions Decision-Making (Oxford University Press, Oxford, 2016) pp. 17-20 (discussing more specifically the Al-Qaida and Taliban Sanctions Committee). 
1267 of $1999^{55}$ and split into two separate committees in $2011,^{56}$ held five times as many informal, unrecorded consultations as formal meetings. ${ }^{57}$ Moreover, none of the sanctions committees directly informs the individuals and entities concerned of their listing (let alone of the reasons for the listing), instead relying on member states to notify the targets of sanctions. ${ }^{58}$ Yet even notification of member states by the committees is often inadequate. ${ }^{59}$ As a consequence, there have been instances when designated individuals and entities have reportedly learned about their listing from non-official sources. ${ }^{60}$

In response to criticism regarding the secretive nature of the working methods of its sanctions committees, the Security Council has repeatedly encouraged them to enhance the transparency of their decision-making. For example, the Security Council has suggested that committees publish their work on the Internet, make summary records of their formal meetings publicly available, and prepare annual reports on their activities. ${ }^{61}$ The 1267 Committee, in 2004, called upon states that propose individuals or groups for inclusion on its sanctions list to provide, to the greatest extent possible, information about their connection with Al-Qaida or the Taliban. ${ }^{62}$ In 2005, it introduced a requirement that such states "shall provide to the Committee a statement of case describing the basis of the proposal". ${ }^{63}$ Yet the Committee still used to give no reasons for its decisions to list or (not) delist individuals or groups. This only changed with Security Council Resolution 1904 of 2009, which directed the Committee to make accessible on its website 'narrative summaries of reasons for listing' the respective individuals and entities on its sanctions list. ${ }^{64}$

55 UN Security Council, Resolution 1267, 15 October 1999 (UN Doc. s/REs/1267).

56 UN Security Council, Resolution 1988, 17 June 2011 (UN Doc. s/Res/1988); UN Security Council, Resolution 1989, 17 June 2011 (UN Doc. S/RES/1989).

57 Devika Hovell, 'The Deliberative Deficit: Transparency, Access to Information and UN Sanctions' in Jeremy Farrall and Kim Rubenstein (eds), Sanctions, Accountability and Governance in a Globalised World (Cambridge University Press, Cambridge, 2009) pp. 92, 95.

58 Watson Institute Targeted Sanctions Project, supra note 54, p. 30.

59 Ibid., pp. 7, 30.

6 o Ibid., p. 7 .

61 See e.g. Un President of the Security Council, Note (29 March 1995), Un Doc. s/1995/234; Note (29 January 1999), UN Doc. S/1999/92, paras. 18-20 (on the work of the sanctions committees).

62 UN Security Council, Resolution 1526 (30 January 2004), UN Doc. s/RES/1526, para. 17.

63 UN Security Council, Resolution 1617 (29 July 2005), un Doc. s/Res/1617, para. 4. See also un Security Council, Resolution 2083 (17 December 2012), un Doc. s/Res/2083, para. 11 (reaffirming the duty to provide a statement of case including the reasons for the listing).

64 UN Security Council, Resolution 1904 (17 December 2009), Un Doc. s/REs/1904, para. 14. See also UN Security Council, Resolution 2083, 17 December 2012, Un Doc. s/Res/2083, 
Nevertheless, the Committee is still not obliged to publish fully reasoned decisions, which would specify the supporting evidence.

2

\section{Legal Limits on the Security Council}

There is a whole range of reasons why the Security Council's obscure working methods, and the lack of a duty to explain the voting behaviour in particular, may be regarded, in terms of policy, as inappropriate or unwise. From a legal point of view, however, this lack of transparency is only problematic if the Security Council and/or its individual members are subject to legal limits at all and if there are ways of reviewing compliance with these legal limits. This Section shows that such legal limits and means of review indeed exist. The Security Council's actions must comply with a range of legal obligations (Section 2.1). Different bodies and entities can review whether they do or not (Section 2.2). Similarly, when voting in the Council, its members are bound to respect a number of legal obligations (Section 2.3), and there are various ways in which their voting behaviour can be reviewed (Section 2.4).

\subsection{Legal Limits on Security Council (In)action}

Are there any legal limits to what the most powerful, quintessentially political organ of the United Nations can do? Article 25 of the UN Charter states that "[t]he Members of the United Nations agree to accept and carry out the decisions of the Security Council in accordance with the present Charter." This provision could be understood to mean that only those decisions that are in accordance with the Charter are binding, while other decisions need not be carried out. According to this-what Anne Peters calls "radical"65_interpretation of Article 25, it seems clear that there are legal limits on Security Council action. However, there are other plausible interpretations of Article 25 , and the travaux préparatoires are not conclusive. ${ }^{66}$ Therefore, the question as to the limitations to the Council's powers must be answered having regard,

para. 14 (welcoming the efforts to make accessible a narrative summary of reasons for listings).

65 Anne Peters, 'Article 25' in Bruno Simma et al. (eds), The Charter of the United Nations: A Commentary ( $3^{\text {rd }}$ ed, Oxford University Press, Oxford, 2012) p. 787, para. 56.

66 Bernd Martenczuk, Rechtsbindung und Rechtskontrolle des Weltsicherheitsrats: Die Überprüfung nichtmilitärischer Zwangsmassnahmen durch den Internationalen Gerichtshof (Duncker und Humblot, Berlin, 1996) pp. 129-133. 
not only to Article 25, but the whole Charter and on the basis of principled considerations. ${ }^{67}$

Hans Kelsen argued in 1951 that, as the preserver of international peace and security, "the Security Council is not bound strictly to comply with existing law."68 A minority of authors still take the position that the Council's powers are unlimited. ${ }^{69}$ Today's majority view, however, is that, given that the Security Council is an organ established by a treaty, it must act within certain legal limits. ${ }^{70}$ The International Court of Justice ('ICJ') stated already in 1947 that " $[t]$ he political character of an organ cannot release it from the observance of treaty provisions established by the Charter when they constitute limitations on its powers or criteria for its judgment."71 It was, however, the International Criminal Tribunal for the former Yugoslavia ('ICTY'), in the famous Tadić case, which best summarized the now prevalent position:

The Security Council is an organ of an international organization, established by a treaty which serves as a constitutional framework for that organization. The Security Council is thus subjected to certain constitutional limitations, however broad its powers under the constitution may be ... [N]either the text nor the spirit of the Charter conceives of the Security Council as legibus solutus (unbound by law). ${ }^{72}$

67 Martenczuk, supra note 66, p. 133; Peters, Article 25 UN Charter, supra note 65, para. 60.

68 Hans Kelsen, The Law of the United Nations: A Critical Analysis of Its Fundamental Problems (Lawbook Exchange, New Jersey, 1951) p. 275.

69 See e.g. Gabriel H. Oosthuizen, 'Playing the Devil's Advocate: The United Nations Security Council is Unbound by Law' (1999) 12 Leiden Journal of International Law p. 521; Michael Reisman, 'The Constitutional Crisis in the United Nations' (1993) 87 American Journal of International Law pp. 91-94.

70 See e.g. Antonios Tzanakopoulos, Disobeying the Security Council: Countermeasures against Wrongful Sanctions (Oxford University Press, Oxford, 2011) pp. 54-56; Dapo Akande, 'The International Court of Justice and the Security Council: Is There Room for Judicial Control of Decisions of the Political Organs of the United Nations?' (1997) 46 International and Comparative Law Quarterly p. 315; Thomas M. Franck, "The "Powers of Appreciation": Who Is the Ultimate Guardian of UN Legality?' (1992) 86 American Journal of International Law pp. 522-523.

71 Conditions of Admission of a State to Membership in the United Nations (Article 4 of the Charter), 28 May 1948, International Court of Justice, Advisory Opinion, [1948] ICJ Rep p. 57, p. 64 .

72 Prosecutor v. Tadić, 2 October 1995, International Criminal Tribunal for the Former Yugoslavia, Appeals Chamber, Decision on the Defence Motion for Interlocutory Appeal on Jurisdiction, Case No IT-94-1-AR72, para. 28. 
Thus, it seems clear that the Security Council is subject to the law. From this it follows that, in principle, not only its actions but also its omissions may be illegal. In exceptional cases, the Council may be under a legal obligation to take a decision, so that failure to act may amount to a violation of international law. ${ }^{73}$

It is also worth stressing that Article 103 of the UN Charter is no obstacle to there being legal limits to Security Council action. As is clear from the wording of this provision, it only applies to "the obligations of the Members of the United Nations", not the Security Council itself. Moreover, it only concerns the relationship between obligations under the Charter and "obligations under any other international agreement", but not obligations under customary international law. ${ }^{74}$

What is still contentious, however, is what exactly the legal limits to the powers of the Security Council are. There is a nearly unanimous view in legal scholarship that, first of all, the Security Council may not violate norms of jus cogens as these are overriding norms of the international legal order binding all subjects of international law. When adopting the UN Charter, member states could not derogate from these peremptory norms ${ }^{75}$ This view finds support in the case law of the ICJ ${ }^{76}$ the

73 Anne Peters, 'Article 24' in Bruno Simma et al. (eds), The Charter of the United Nations: A Commentary ( ${ }^{\text {rd }}$ ed) (Oxford University Press, Oxford, 2012) p. 761, paras. 36-40.

74 Peters, Article 25 UN Charter, supra note 65, paras. 209-211.

75 See e.g. David Schweigman, The Authority of the Security Council under Chapter viI of the UN Charter: Legal Limits and the Role of the International Court of Justice (Kluwer Law International, The Hague, 2001) pp. 197-201; Tzanakopoulos, supra note 70, pp. 70-72; Erika de Wet and André Nollkaemper, 'Review of Security Council Decisions by National Courts' (2002) 45 German Yearbook of International Law pp. 181-184. But see Evelyne Lagrange, 'Le Conseil de sécurité des Nations Unies peut-il violer le droit international?' (2004) 2 Revue belge de droit international pp. 582-585; and Bernd Martenczuk, 'The Security Council, the International Court and Judicial Review: What Lessons from Lockerbie?' (1999) 10 European Journal of International Law pp. 545-546.

${ }_{76}$ Application of the Convention on the Prevention and Punishment of the Crime of Genocide (Bosnia and Herzegovina. v. Serbia and Montenegro), 13 September 1993, International Court of Justice, Provisional Measures, Order, separate opinion by Lauterpacht, J., [1993] ICJ Rep p. 325, para. 100:

The concept of jus cogens operates as a concept superior to both customary international law and treaty. The relief which Article 103 of the Charter may give the Security Council in case of conflict between one of its decisions and an operative treaty obligation cannot - as a matter of simple hierarchy of norms - extend to a conflict between a Security Council resolution and jus cogens. Indeed, one only has to state the opposite proposition thus - that a Security Council resolution may even require participation in genocide - for its unacceptability to be apparent. 
former Court of First Instance of the European Communities ('CFI' $)^{77}$ and national courts. ${ }^{78}$

Second, it seems clear that the Security Council is bound by the purposes and principles of the United Nations. ${ }^{79}$ This legal limit to the Council's powers is expressly contained in Article 24(2) of the Charter, which provides that "the Security Council shall act in accordance with the Purposes and Principles of the United Nations." As Judge Weeramantry of the ICJ has remarked, this duty "is imperative and the limits are categorically stated." 80 It seems beyond contention that a decision of the Council that does not at least aspire to reach one of the purposes of the United Nations listed in Article 1 would be ultra vires and therefore illegal..$^{81}$ However, these purposes are so broadly defined that almost any decision could be said to further it.

Third, many authors argue that, since international organizations are bound by their internal law, notably by their constituent instrument, not only the purposes and principles but the entire UN Charter constitutes a legal limit on Security Council action. ${ }^{82}$ According to this view, limits imposed on the Security Council by the Charter include the rules on competences, ${ }^{83}$ the obligation to determine the existence of a "threat to the peace" according to Article $39,{ }^{84}$

Ahmed Ali Yusuf and Al Barakaat International Foundation v. Council and Commission, 21 September 2005, Court of First Instance of the European Communities, Case T-306/o1, ECR II-03533, paras. 277-281; Yassin Abdullah Kadi v. Council and Commission, 21 September 2005, Court of First Instance of the European Communities, Case T-315/01, ECR II03649, paras. 226-230.

78 See e.g. Swiss Federal Supreme Court, 14 November 2007, 125 Entscheidungen des Schweizerischen Bundesgerichts (BGE) 133 II p. 450, pp. 460-463.

79 See e.g. de Wet, supra note 37, pp. 191-215; Schweigman, supra note 75, pp. 167-182; Akande, supra note 7o, pp. 316-317; Lagrange, supra note 75 , pp. 585-587.

8o Questions of Interpretation and Application of the 1971 Montreal Convention arising from the Aerial Incident at Lockerbie (Libyan Arab Jamahiriya v. U K), 14 April 1992, International Court of Justice, Provisional Measures, Order, dissenting opinion by Weeramantry, J., [1992] ICJ Rep p. 3, p. 171. See also Application of the Convention on the Prevention and Punishment of the Crime of Genocide (Bosnia and Herzegovina. v. Serbia and Montenegro), 13 September 1993, International Court of Justice, Provisional Measures, Order, separate opinion by Lauterpacht, J., [1993] ICJ Rep p. 325, para. 101 (arguing that the Security Council must act in accordance with the purposes and principles of the United Nations in discharging its duties to maintain international peace and security).

81 Peters, Article 25 UN Charter, supra note 65, para. 77.

82 Martenczuk, supra note 66, pp. 120-163; Tzanakopoulos, supra note 70, pp. 57-59; Peters, Article 25 UN Charter, supra note 65, paras. 87-89.

83 Peters, Article 25 UN Charter, supra note 65, para. 90.

84 De Wet, supra note 37, pp. 133-177; Tzanakopoulos, supra note 70, pp. 60-64; Talmon, supra note 9, pp. 184-185. 
as well as the obligation to take proportionate action in response to such a threat. ${ }^{85}$

Fourth, there is strong support for the position that the Security Council is bound to comply with human rights, at the very least those guaranteed by the Universal Declaration of Human Rights ('UDHR'). ${ }^{86}$ Doctrinally, there are different ways in which such a duty can be explained. One may, for example, point to the fact that among the purposes of the United Nations listed in $\mathrm{Ar}$ ticle 1 of the Charter, which according to Article 24(2) are binding on the Security Council, is that of "promoting and encouraging respect for human rights and for fundamental freedoms". ${ }^{87,88}$ Or one may point out that the United Nations, by establishing a system of human rights protection, has created a legal expectation that its organs, including the Security Council, will themselves respect these rights. ${ }^{89}$ Or one may argue that the Council, as an organ of an organization endowed with international legal personality, must at least comply with those human rights obligations that have become part of customary international law. ${ }^{90}$

A more contentious proposition is that, fifth, the Security Council is bound to comply, not only with jus cogens and human rights norms, but with the whole body of general international law, that is, all customary law and general principles of law. ${ }^{91}$ Some authors putting forth this proposition make reference to Article 1(1) of the Charter, which provides, as one of the purposes of the United Nations, that international disputes or situations that might lead to a breach of the peace are to be adjusted or settled "in conformity with the principles of justice and international law". ${ }^{92}$ Other authors, in contrast, point

85 Tzanakopoulos, supra note 70, pp. 64-67; Lagrange, supra note 75, pp. 587-591.

86 Peters, Article 25 UN Charter, supra note 65, paras. 120-121.

87 UN Charter, Art 1, para. 3. See also UN Charter, Art 55, para. c (stipulating that in order to create conditions of stability and well-being, the UN shall promote universal respect for human rights and fundamental freedoms).

88 See e.g. Application of the Convention on the Prevention and Punishment of the Crime of Genocide (Bosnia and Herzegovina. v. Serbia and Montenegro), 13 September 1993, International Court of Justice, Provisional Measures, Order, separate opinion by Lauterpacht, J., [1993] ICJ Rep p. 325, para. 101; Al-Dulimi and Montana Management Inc. v. Switzerland, 21 June 2016, European Court of Human Rights (Grand Chamber), App. No 5809/08, para. 139.

89 See e.g. de Wet and Nollkaemper, supra note 75, pp. 173-175.

9o Akande, supra note 70, pp. 323-324.

91 See e.g. Tzanakopoulos, supra note 70, pp. 72-79; Mehrdad Payandeh, 'Rechtskontrolle des UN-Sicherheitsrates durch staatliche und überstaatliche Gerichte' (2006) 66 Zeitschrift für ausländisches öffentliches Recht und Völkerrecht pp. 46-47.

Akande, supra note 70, pp. 317-321. 
out that "justice and international law" are only mentioned in the context of the peaceful settlement of disputes but not in that of collective measures under Chapter VII, concluding that the Council must not comply with general international law when it is acting to maintain or restore international peace and security. ${ }^{93}$

\section{$2.2 \quad$ Legal Review of Security Council (In)action}

The question of legal limits to Security Council (in)action is to be distinguished from the question of whether it is possible to review if the Council stays within these limits. That the Council is bound by the law does not mean that there are mechanisms for reviewing its acts. On the other hand, the absence of specific control mechanisms in international law does not preclude the possibility of it being bound. Nevertheless, the two questions are closely linked. For what is the point of legal limits if there is no one who could check whether they are complied with? ${ }^{94}$ And what, on the other hand, is the point of reviewing an act if there are no legal standards by which to judge it?

\subsubsection{Review by Courts}

There is not one central, superior judicial institution that would be charged with supervising the Security Council and that could quash its decisions. Nevertheless, there are manifold ways in which the legality of Security Council action may be (and indeed is) reviewed by various courts and quasi-judicial bodies.

First, the $I C J$ may directly review the legality of a Security Council decision in an advisory proceeding. Article 96(1) of the UN Charter authorizes the General Assembly and the Security Council to request the ICJ to give an advisory opinion on any legal question. Other organs of the United Nations and specialized agencies may request advisory opinions on legal questions arising within the scope of their activities. ${ }^{95}$ The legality of action (to be) taken by the Security Council is undoubtedly a "legal question" in the sense of Article 96. ${ }^{96}$ In addition, the legality of a Council decision can arise incidentally in advisory proceedings when the Court has to determine the legal consequences

93 Martenczuk, supra note 75 , pp. 544-546; Lagrange, supra note 75 , pp. $57^{8-582}$. This argument goes back to Hans Kelsen: Kelsen, supra note 68, pp. 294-295.

94 See Reisman, supra note 69, p. 92.

95 UN Charter, Art 96, para. 2.

$96 \quad$ Akande, supra note 7o, pp. 327-328. 
of Council action. This has in fact happened in the Certain Expenses opinion ${ }^{97}$ and the Namibia opinion. ${ }^{98}$

Second, although the $I C J$ cannot directly review Security Council acts in contentious proceedings because only states can be parties to such proceedings, ${ }^{99}$ an incidental review is possible. A case may arise between two or more states where a resolution of the Security Council is part of the law that the ICJ is called upon to apply. In such a situation, the Court may have to determine whether that resolution is valid in the first place.$^{100}$ This is a question the Court is allowed to address, since it can consider any legal question that may be at issue between the parties of a dispute. ${ }^{101}$ One may imagine a number of different scenarios where the Court would have to examine whether a given act of the Security Council is valid so as to be able to decide the case before it. If, for example, a boundary dispute between Iraq and Kuwait came before the ICJ, it would be required to examine whether the Security Council had in fact the power to establish the Boundary Commission that demarcated the boundary as it now exists. ${ }^{102}$ In the Lockerbie case, the ICJ did at least not exclude the possibility that it would review the legality of Security Council Resolution 748 at the merits stage. ${ }^{103}$

Third, in its famous Tadic ruling, the ICTY incidentally reviewed-at length - the legality of the Security Council resolution by which it had been established, eventually affirming it. ${ }^{104}$ The International Criminal Tribunal for

97 Certain Expenses of the United Nations (Article 17, paragraph 2, of the Charter), 20 July 1962, International Court of Justice, Advisory Opinion, [1962] ICJ Rep p. 151, pp. 163-168. See de Wet, supra note 37 , pp. 30-34.

98 Legal Consequences for States of the Continued Presence of South Africa in Namibia (South West Africa) notwithstanding Security Council Resolution 276 (1970), 21 June 1971, International Court of Justice, Advisory Opinion, [1971] ICJ Rep p. 16, para. 89. See de Wet, supra note 37, pp. 34-41.

99 Statute of the International Court of Justice (26 June 1945), 1 UNTS p. 16, Art 34(1).

$100 \quad$ Akande, supra note 70, pp. 331-333.

101 United States Diplomatic and Consular Staff in Tehran (US v. Iran), 24 May 1980, International Court of Justice, Judgment, ICJ Rep 3, para. 40.

102 See Akande, supra note 70, pp. 332-333, for this (and a further) example.

103 Questions of Interpretation and Application of the 1971 Montreal Convention arising from the Aerial Incident at Lockerbie (Libyan Arab Jamahiriya v. uk ), 14 April 1992, International Court of Justice, Provisional Measures, Order, dissenting opinion by Weeramantry, J., [1992] ICJ Rep p. 3, para. 38.

104 Prosecutor v. Tadić, 2 October 1995, International Criminal Tribunal for the Former Yugoslavia, Appeals Chamber, Decision on the Defence Motion for Interlocutory Appeal on Jurisdiction, Case No IT-94-1-AR72, paras. 13-48. The Appeals Chamber of the Special Tribunal for Lebanon refused to follow this approach, arguing it had no authority to review 
Rwanda ('ICTR') later did the same-although less extensively—in Prosecutor v. Joseph Kanyabashi. ${ }^{105}$

Fourth, the $I C C$, according to Article 19(1) of its Statute, ${ }^{106}$ is entitled, and indeed obliged, to "satisfy itself that it has jurisdiction in any case brought before it." Based on this provision, the ICc has the power to review the legality of two types of Security Council decisions, namely referral decisions according to Article $13(\mathrm{~b})$ and deferral decisions according to Article 16 of the ICc Statute. When the Security Council refers a situation to the ICC, the Court must establish whether that referral respects the conditions laid down in Article 13(b) of the ICc Statute. Thus, it has the competence to verify, at the very least, whether the Security Council has followed the correct voting procedure, whether it has acted under Chapter VII of the UN Charter and made a determination according to Article 39 of the Charter, and whether it has indeed adopted a resolution referring the situation to the ICC. ${ }^{107}$ Some authors suggest that the Court's power to review referral decisions is limited to these 'formal' grounds of review and that it is not authorized to review them in substance, that is, to assess the grounds for the Council's determination according to Article 39 of the Charter or for the referral of a situation to the Court. ${ }^{108}$ Others, in contrast, take the position that, while the Security Council undoubtedly enjoys wide discretion with regard to these determinations, it is still required to act within the limits of the purposes and principles of the Charter, so that "the Security Council cannot refer any situation to the Court."109 Accordingly, the ICC would

Security Council Resolution 1757, which had established the Tribunal: Prosecutor v. Salim Jamil Ayyash et al., 24 October 2012, Special Tribunal for Lebanon, Appeals Chamber, Decision on the Defence Appeals Against the Trial Chamber's "Decision on the Defence Challenges to the Jurisdiction and Legality of the Tribunal", Case No STL-11-01/PT/AC/AR90.1, paras. 36-50. See, however, the separate and partially dissenting opinion by Baragwanath, J., paras. $45^{-81}$, arguing that the Tribunal does have the competence to judicially review the Council's resolution.

105 Prosecutor v. Kanyabashi, 18 June 1997, International Criminal Tribunal for Rwanda, Decision on the Defence Motion on Jurisdiction, Case No ICTR-96-15-T, paras. 17-29.

106 Rome Statute of the International Criminal Court, opened for signature 17 July 1998, 2187 unTs p. 90.

107 Gabriël H. Oosthuizen, 'Some Preliminary Remarks on the Relationship between the Envisaged International Criminal Court and the UN Security Council' (1999) 46 Netherlands International Law Review pp. 319-321.

108 Ibid., p. 322.

109 William A. Schabas, The International Criminal Court: A Commentary on the Rome Statute (Oxford University Press, Oxford, 2010) p. 301. See also Luigi Condorelli and Santiago Villalpando, 'Referral and Deferral by the Security Council' in Antonio Cassese et al. (eds), The Rome Statute of the International Criminal Court: A Commentary, Volume I (Oxford 
be able to determine whether the Council has acted ultra vires. ${ }^{110}$ Similarly, the ICC must satisfy itself that the request of the Security Council for the deferral of an investigation or prosecution is in compliance with the requirements of Article 16 of the ICC Statute. Thus, the Court can verify whether the deferral request is contained in a Security Council resolution that has been adopted under Chapter VII, following the correct voting procedure. ${ }^{111}$ It could arguably also review whether Article 16 is used - as its drafters seem to have intendedon a case-by-case basis by reference to a particular situation rather than to grant, in advance, blanket immunity for a whole category of persons. ${ }^{112}$ Finally, also with regard to deferrals the ICC could, according to some authors, review whether the Council has respected the purposes and principles of the United Nations and not acted ultra vires. ${ }^{113}$

Fifth, a number of other international (quasi-)judicial bodies have examined, at least indirectly, decisions of the Security Council when reviewing acts of member states that implement these decisions. Most of these decisions concern the imposition of sanctions. The European Court of Human Rights ('ECtHR') has repeatedly reviewed national acts implementing Security Council decisions. ${ }^{114}$ In al-Dulimi v. Switzerland, for example, a Chamber of the ECtHR held that action taken by a state in compliance with a sanctions regime

University Press, Oxford, 2002) pp. 627,641 (arguing that the ICc should determine whether the Council has acted in conformity with the purposes and principles of the UN Charter). Schabas, supra note 109, p. 301. Note that Articles 15bis(9) and 15ter(4) of the Kampala amendments to the ICC Statute regarding the crime of aggression explicitly state that the ICC is not bound by the Security Council's (or any other organ's) determination of an act of aggression: Amendments on the crime of aggression to the Rome Statute of the International Criminal Court, done at Kampala, 11 June 2010.

111 Oosthuizen, supra note 107, pp. 331-334; Condorelli and Villalpando, supra note 109, p. 650.

112 As was the case with UN Security Council, Resolution 1422 (12 July 2002), UN Doc. S/RES/1422. See Nigel White and Robert Cryer, "The ICC and the Security Council: An Uncomfortable Relationship' in José Doria et al. (eds), The Legal Regime of the International Criminal Court: Essays in Honour of Professor Igor Blishchenko (Martinus Njihoff, Leiden, 2009) pp. 455, 465-466, 468-469; Zsuzsanna Deen-Racsmány, 'The ICc, Peacekeepers and Resolution 1422: Will the Court Defer to the Council?' (2002) 49 Netherlands International Law Review pp. 383-384. On how a challenge to such a deferral decision of the Security Council could reach the ICc, see Robert Cryer and Nigel White, 'The Security Council and the International Criminal Court: Who's Feeling Threatened?' in Olympia Bekou and Robert Cryer (eds), The International Criminal Court (Ashgate Publishing, Aldershot, 2004) pp. 495, 515-516.

113 Condorelli and Villalpando, supra note 109, p. 650.

114 See e.g. Nada v. Switzerland, 12 September 2012, European Court of Human Rights, App. No 10593/o8, Reports of Judgments and Decisions 2012-V, p. 213. 
of the Security Council will only be justified if that regime "protects fundamental rights in a manner which can be considered at least equivalent to that for which the Convention provides". 115 In the view of the Chamber, the sanctions regime against the former Iraqi government under Resolution 1483 did not meet this requirement. ${ }^{116}$ The Grand Chamber observed that "where a State relies on the need to apply a Security Council resolution in order to justify a limitation on the rights guaranteed by the Convention, it is necessary for the Court to examine the wording and scope of the text of the resolution in order to ensure, effectively and coherently, that it is consonant with the Convention."117 It concluded that, when implementing a Council resolution requiring the listing of individuals, states must, at the very least, allow those individuals to submit evidence to a court to seek to show that their inclusion on the list has been arbitrary.118 The un Human Rights Committee, in Sayadi and Vinck v. Belgium, reviewed national measures implementing Security Council Resolution 1267 and subsequent related resolutions for their conformity with the rights guaranteed by the International Covenant on Civil and Political Rights ('ICCPR'), ${ }^{119}$ finding a violation of Articles 12 and $17 .{ }^{120}$ In the Kadi/Yusuf cases, the CFI applied a relaxed review of the sanctions regime established by Resolution 1267, checking its lawfulness with regard to jus cogens, ${ }^{121}$ while the European Court of Justice ('ECJ') performed a full-fledged review of the implementing regulation of the European Union ('EU') and, thereby, indirectly of the sanctions regime imposed by the Security Council. ${ }^{122}$

115 Al-Dulimi and Montana Management Inc. v. Switzerland, 26 November 2013, European Court of Human Rights, App. No 5809/o8, para. 114, <http://hudoc.echr.coe.int/eng?i=001 $-138948>$.

116 Ibid., paras. 118-122.

117 Al-Dulimi and Montana Management Inc. v. Switzerland, 21 June 2016, European Court of Human Rights, Grand Chamber, App. No 5809/o8, para. 139.

118 Ibid., para. 151.

119 International Covenant on Civil and Political Rights, opened for signature 16 December 1969, 999 UNTS p. 171.

120 Sayadi and Vinck v. Belgium, 29 December 2008, Human Rights Committee, Communication No 1472/2006 (UN Doc. CCPRlC/94/D/1472/2006).

121 Ahmed Ali Yusuf and Al Barakaat International Foundation v. Council and Commission, 21 September 2005, Court of First Instance of the European Communities, Case T-306/o1, ECR II-03533, paras. 277-281; Yassin Abdullah Kadi v. Council and Commission, 21 September 2005, Court of First Instance of the European Communities, Case T-315/01, ECR II03649, paras. 226-230.

122 Kadi and Al Barakaat Int'l Found. v. Council, 3 September 2008, European Court of Justice, Joined Cases C-402/05 P and C-415/05 P, ECR I-06351, para. 326. Although the ECJ claimed 
Sixth, domestic courts may be required to review, as an incidental question, the legality of a Security Council resolution. They can do so, for example, when an action contesting the adoption of a domestic measure implementing the resolution itself is brought, when a tort action against the state is brought, or when criminal proceedings are instituted against individuals placed on one of the Council's terrorist sanctions lists. ${ }^{123}$ Cases in which domestic courts were required to review the validity of Security Council action have included, for example, challenges to the Council's power to establish the ICTY, ${ }^{124}$ to the conformity of the procedures of the ICTR with fair trial standards, ${ }^{125}$ and to the compatibility of national measures implementing the terrorist sanctions regime with various human rights guarantees. ${ }^{126}$

\subsubsection{Review by Other Bodies and Entities}

Not only various courts, but also a number of other bodies and entities may review decisions of the Security Council for their compliance with international law.

First and foremost, as is made clear by Article 24(1) of the UN Charter, the Security Council, in fulfilling its responsibility for the maintenance of international peace and security, acts on behalf of the entire membership of the United Nations. Thus, the Council is accountable to the members: they have "a right of supervision on how this responsibility is exercised on their behalf."127

that it is not reviewing the relevant Security Council resolutions (paras. 286-287), it was only able to make that claim because it assumed that the European Community had a freedom of choice with regard to implementation (para. 298), which is a highly problematic assumption. See Larissa van den Herik and Nico Schrijver, 'Eroding the Primacy of the UN System of Collective Security: The Judgment of the European Court of Justice in the Cases of Kadi and Al Barakaat' (2008) 5 International Organizations Law Review p. 335 .

123 De Wet and Nollkaemper, supra note 75, p. 192.

124 Milosevic v. The Netherlands, 31 August 2001, The Hague District Court, Judgment in interlocutory injunction proceedings, trans. in (2001) 48 Netherlands International Law Review p. 357 .

125 Swiss Federal Supreme Court, 3 September 2001, 1A.129/2001.

126 See e.g. Swiss Federal Supreme Court, 14 November 2007, 133 BGE II 450; Abdelrazik v. Canada (Minister of Foreign Affairs), 4 June 2009, Canadian Federal Court, [2010] 1 FCR p. 267. See Antonios Tzanakopoulos, 'Domestic Court Reactions to un Security Council Sanctions' in August Reinisch (ed), Challenging Acts of International Organizations Before National Courts (Oxford University Press, Oxford, 2010) p. 54, for an overview.

127 Eric Suy, 'The Role of the United Nations General Assembly' in Georges Abi-Saab (ed), The Changing Constitution of the United Nations (British Institute of International \& Comparative Law, London, 1997) pp. 55, 64. 
Within the organization, the primary means of ensuring this accountability are the annual and special reports that Article 24(3) of the UN Charter obliges the Council to submit to the General Assembly, in which all members are represented. According to Article 15(1) of the Charter, "these reports shall include an account of the measures that the Security Council has decided upon or taken to maintain international peace and security."128 While originally the Council's annual reports were mainly descriptive, there have recently been several efforts to make them more informative and analytical. ${ }^{129}$ This reflects an understanding among member states that, in order to fulfil their accountability function, the reports must contain explanations for the decisions taken (or not taken). ${ }^{130}$ The General Assembly is only able to scrutinize the Security Council's acts (and omissions), including for their conformity with international law, if the Council explains the reasons for them. ${ }^{311}$ While the General Assembly can thus review the legality of Council action, it does not have the power to adopt any political or legal sanctions against it upon a report.

Regional organizations of states may also check the lawfulness of Security Council action. In 1998, for instance, the Assembly of the Heads of State and Government of the Organization of African Unity adopted a resolution declaring that it would no longer comply with the Security Council resolutions imposing sanctions against Libya, "owing to the fact that the said resolutions violate Article 27 paragraph 3, Article 33 and Article 36 paragraph 3 of the United Nations Charter."132 While not directly threatening disobedience, also the Parliamentary Assembly of the Council of Europe has engaged in legal review of Security Council action. In 2008, it passed a resolution in which it found that the targeted sanctions system established by the Council in no way fulfils the minimum standards of the European Convention on Human Rights ('ECHR') and the ICCPR and thus "violate[s] the fundamental principles of human rights and the rule of law". Accordingly, it urged the Council "to overhaul the procedural and substantive rules governing targeted sanctions."133

Finally, can individual member states review decisions of the Security Council for their compliance with international law and, if they find them to

\footnotetext{
128 UN Charter, Art 15(1).

129 Sievers and Daws, supra note 10, p. 589.

130 Peters, Article 24 UN Charter, supra note 73, para. 56.

131 Ibid.

132 Resolution adopted by the Heads of State and Government of the Organization of African Unity, The Crisis Between the Great Socialist People's Libyan ArabJamahiriya and the United States of America and the United Kingdom, 10 June 1998 (AHG/Dec. 127 (XXXIV)).

133 Parliamentary Assembly of the Council of Europe, Resolution 1597 (23 January 2008), $5^{\text {th }}$ Session, Doc. 11454, paras. 6, 7.1.
} 
be illegal, refuse to carry them out? Some scholars argue that they can. There are different ways of justifying this position. As explained above, adopting a 'radical' interpretation of Article 25 of the Charter, one may argue that the member states are only obliged to comply with those decisions of the Council that are "in accordance with the present Charter" and are thus free to disobey those decisions that are not. ${ }^{134}$ Or one may assert that a Council decision in violation of international law constitutes an internationally wrongful act, engaging the responsibility of the United Nations. Disobedience by a state could then be qualified as a countermeasure, precluding wrongfulness. ${ }^{135}$ Or, finally, one may assert that a state may lawfully resist a Security Council resolution if it has exhausted all mechanisms available for establishing the illegality of that resolution and its view is supported at least by part of the international community. ${ }^{136}$ All three positions presuppose that it is possible and appropriate for states to determine the legality of a given Security Council decision. ${ }^{137}$

\subsection{Legal Limits on States' Voting Behaviour in the Security Council}

Not only the acts and omissions of the Security Council as a collective organ, but also those of its individual members are subject to legal limits. When a state participates in the decision-making process of an international organization, this can be qualified as an act of that state which may entail its international responsibility. At least as long as they act under instructions from their home government, the voting behaviour of state representatives in international organizations is attributable to their state. ${ }^{138}$ As the Permanent Court of International Justice observed with regard to the Council of the League of Nations, this body was "composed of representatives of Members, that is to say, of persons delegated by their respective Governments, from whom they receive instructions and whose responsibility they engage."139 This equally applies to

\footnotetext{
134 See e.g. de Wet, supra note 37, pp. 375-378. See supra p. 13.

135 See e.g. Tzanakopoulos, supra note 70, pp. 174-190.

136 Sufyan Droubi, Resisting United Nations Security Council Resolutions (Routledge, London, 2014).

137 Tzanakopoulos, supra note 70, pp. 112-137.

138 Frederik Naert, 'Binding International Organisations to Member State Treaties or Responsibility of Member States for Their Own Actions in the Framework of International Organisations' in Jan Wouters et al. (eds), Accountability for Human Rights Violations by International Organisations (Intersentia, Antwerp, 2010) pp. 129, 163; Ana Sofia Barros and Cedric Ryngaert, "The Position of Member States in (Autonomous) Institutional DecisionMaking' (2014) 11 International Organizations Law Review pp. 6o-61.

139 Article 3, Paragraph 2, of the Treaty of Lausanne, 21 November 1921, Permanent Court of International Justice, Advisory Opinion, [1921] PCIJ (Ser. B) No 12, p. 29.
} 
votes in the Security Council, which are cast by government representatives who are subject to instructions. The vote in the decision-making organ of an international organization is thus attributable to the member state. ${ }^{140}$

The decision adopted as a result of the votes cast, in contrast, constitutes collective conduct of the organ that is attributable to the international organization. It is for this reason that the ICJ, in its judgment in Application of the Interim Accord of 13 September 1995 (The Former Yugoslav Republic of Macedonia v. Greece), made a clear distinction between, on the one hand, Greece's objection to the admission of the Former Yugoslav Republic of Macedonia ('FYROM') to the North Atlantic Treaty Organization ('NATO') and, on the other, NATO's decision to defer the invitation to the FYROM to join NATO. ${ }^{141}$ Having concluded that the conduct of Greece within this international organization "can be assessed independently of NATO's decision", ${ }^{142}$ the ICJ reviewed Greece's objection in light of its treaty obligations towards the FYROM.

It is true that according to Article 59(2) of the Articles on the Responsibility of International Organizations ('ARIO') of the International Law Commission ('ILC'),

[a]n act by a State member of an international organization done in accordance with the rules of the organization does not as such engage the international responsibility of that State under the terms of this article. ${ }^{143}$

However, such acts may fall under the regime of state responsibility instead. The ILC has explicitly recognized in its Commentary to the ARIO that the fact that a state does not incur responsibility under the regime of international organization responsibility "does not imply that the State would then be free to ignore its international obligations". "These obligations", the ILC Commentary continues, "may well encompass the conduct of a State when it acts within

140 Barros and Ryngaert, supra note 138, p. 71; Naert, supra note 138, pp. 163-164; Paolo Palchetti, 'Sulla responsibilità di uno stato per il voto espresso in seno ad un'organizzazione internazionale' (2012) 45 Rivista di diritto internazionale pp. 354-355. But see Evelyne Lagrange, La représentation institutionelle dans l'ordre international (Kluwer Law International, The Hague, 2002) pp. 326-343.

141 Application of the Interim Accord of ${ }_{3}$ September 1995 (The Former Yugoslav Republic of Macedonia v. Greece), 5 December 2011, International Court of Justice, Judgment, [2011] ICJ Rep p. 644, paras. 42-43.

142 Ibid., para. 43.

143 International Law Commission, Report of the Work of its Sixty-Third Session, 2011, UN Doc. A/66/10, commentary to $\operatorname{Art} 59(2)$. 
an international organization", breach of which would entail responsibility according to the ILC Articles on State Responsibility. ${ }^{144}$

The voting behaviour of a state in an international organization is thus not only attributable to that state, but it can also constitute a breach of an international obligation of that state. Whether a vote will entail international responsibility will depend on the scope and nature of a given obligation, in particular on whether it imposes a particular course of action on the state in the decision-making process of an international organization. ${ }^{145}$ For the present context, the most important treaties imposing on states a particular voting behaviour in international organizations are the UN Charter and human rights treaties.

\subsubsection{Legal Limits Arising under the UN Charter}

When the members of the Security Council participate in debates and votes in the Council, they do not only represent their respective states but also act as part of an organ of the United Nations. More than that, the Security Council has a restricted membership and acts, according to Article 24(1) of the Charter, "on behalf" of all members of the United Nations. Therefore, the members represented in the Council have a special responsibility towards the other members of the organization. ${ }^{146}$ The representative of Costa Rica put it as follows in the General Assembly:

In accordance with the provisions of the Charter, the Security Council acts on behalf of all Members of the United Nations. Its members, whether permanent or elected, represent equally all States Members of the Organization and they are, therefore, responsible to them. ${ }^{147}$

\footnotetext{
144 Ibid., commentary to Art 58(5) (which also applies to Art 59).

145 Naert, supra note 138, p. 164; Palchetti, supra note 140, pp. 356-362.

146 Anne Peters, 'The Responsibility to Protect: Spelling Out the Hard Legal Consequences for the UN Security Council and Its Members' in Ulrich Fastenrath et al. (eds), From Bilateralism to Community Interest: Essays in Honour of Bruno Simma (Oxford University Press, Oxford, 2011) p. 297, at p. 314 ('Spelling Out'). See also Anne Peters, 'The Security Council's Responsibility to Protect' (2011) 8 International Organizations Law Review pp. 24-25.

147 UN General Assembly, $56^{\text {th }}$ Session, $25^{\text {th }}$ plenary meeting (15 October 2001), UN Doc. A/56/PV.25, p. 3. See also Conditions of Admission of a State to the United Nations (Charter, Art 4), 28 May 1948, International Court of Justice, Advisory Opinion, dissenting opinion by Basdevant, Winiarski, McNair and Read, JJ., [1948] ICJ Rep p. 57, pp. 91-92:

$[\mathrm{T}]$ he members of the Security Council, in whatever capacity they may be there, are participating in the action of an organ which in the discharge of its primary responsibility for the maintenance of international peace and security is acting on behalf of all the Members of the United Nations.
} 
The members of the Council act as delegates of all other members of the United Nations and can in this sense be characterized as "trustees of the international community". 148

The rights of participation in the Security Council thus serve the fundamental values of the international community. Accordingly, they may not be exercised in a manner that would undermine these very values. In other words, the voting rights of the members of the Security Council, as "trustees of the international community", may not be exercised arbitrarily but instead are subject to (legal) limits, even though these may be widely drawn..$^{149}$

As a very minimum, when voting in the Security Council, the Council members must comply with their obligation under Article 2(2) of the UN Charter to act in good faith. This legal limit on the voting behaviour in the Council has been recognized by the judges of the ICJ Basdevant, Winiarski, McNair, and Read in their dissenting opinion in the advisory opinion on Conditions of Admission. While acknowledging that, when voting in the Council, its members have "the right and the duty to take into account all the political considerations which are in their opinion relevant to a decision", 150 they held that they do not enjoy unlimited freedom but must use their voting power "in good faith, in accordance with the Purposes and Principles of the Organization and in such a manner as not to involve any breach of the Charter". ${ }^{151}$ The disagreement between the judges in the Admission case did not relate to this specific issue: all of them agreed "that the discretion inherent in the right to vote must be exercised in good faith".152 Jean Spiropoulos has similarly argued that, although the members of the Council have a wide discretionary power in exercising their functions, "[l]eur pouvoir discrétionnaire devient une illégalité lorsqu'il est exercé de façon abusive." ${ }^{153}$ Any vote not given in good faith constitutes, according to

\footnotetext{
148 Peters, Spelling Out, supra note 146, p. 314.

149 Matthias Herdegen, Völkerrecht ( $15^{\text {th }}$ ed) (Beck, Munich, 2016) pp. 318-319. See also Nigel D. White, 'Decision-Making' in Jan Klabbers and Åsa Wallendahl (eds), Research Handbook on the Law of International Organizations (Edward Elgar, Cheltenham, 2011) p. 225, 243 (highlighting the existence of legal limitations to voting in the Council).

150 Conditions of Admission of a State to the United Nations (Charter, Art 4), 28 May 1948, International Court of Justice, Advisory Opinion, [1948] ICJ Rep p. 57, dissenting opinion by Basdevant, Winiarski, McNair and Read, JJ, p. 91.

$15^{1}$ Ibid., p. 93 .

$15^{2}$ Bin Cheng, General Principles of Law as Applied by International Courts and Tribunals (Cambridge University Press, Cambridge, 1982) p. 135.

153 Jean Spiropoulos, 'Labus du droit de vote par un Membre du Conseil de Sécurité' (1948) 1 Revue Hellénique de Droit International pp. 4-6.
} 
Spiropoulos, such an abuse of power. ${ }^{154}$ Robert Kolb has pointed out that any margin of discretion in voting in the Council is limited by the obligation to act in good faith and that even the power to veto, despite its eminently political nature, remains subject to the legal order and may not be abused. ${ }^{155}$ This is reflected in UN practice, for example in the joint statement made by the great powers in San Francisco in defence of the Yalta Formula, according to which "[i]t is not to be assumed ... that the permanent members, any more than the non-permanent members, would use their 'veto' power wilfully to obstruct the operation of the Council."156 In its Uniting for Peace resolution, the General Assembly refers to "the duty of the permanent members ... to exercise restraint in the use of the veto." 157

Accordingly, the exercise of the right to vote in the Council will amount to a breach of the obligation to act in good faith if it undermines the purposes and principles of the United Nations. ${ }^{158}$ Most importantly, the Council members are obliged to employ their vote in a manner that coincides with the primary purpose of the organization, maintenance of international peace and security. ${ }^{159}$ Thus, it has convincingly been argued, a vote cast by a Council member that has nothing to do with this purpose would be illegal. ${ }^{160}$ An example of such an exercise of the voting right is the veto cast by China in 1997 against a draft resolution authorizing the sending of military observers to Guatemala,

154 Ibid., p. 7 .

155 Robert Kolb, La bonne foi en droit international public: Contribution à l'étude des principes généraux de droit (Presses Universitaires de France, Geneva and Paris, 2000) pp. 510-517.

${ }_{156}$ Statement by the Delegations of the Four Sponsoring Governments on 'The Yalta Formula' on Voting in the Security Council (8 June 1945), UNCIO Vol XI p. 710), para. I.8., reprinted in Bailey and Daws, supra note 28 , p. 455.

157 UN General Assembly, Resolution 377 (v) (3 November 1950), UN Doc. A/REs/377(v), preambular para. 5 .

$15^{8}$ Martenczuk, supra note 66, p. 80; Odette Murray, 'Piercing the Corporate Veil: The Responsibility of Member States of an International Organization' (2011) 8 International Organizations Law Review pp. 341-342. According to Spiropoulos, the obligation to act in accordance with the purposes and principles of the United Nations constitutes a separate legal limit on the voting behaviour of the Council members: Spiropoulos, supra note 153, p. 4. However, the obligation to act in accordance with the purposes and principles according to UN Charter, Art 24(2) binds the Security Council, not its members. Therefore, the better view is to regard it as forming part of the members' obligation to act in good faith according to Art 2(2).

159 Andrew J. Carswell, 'Unblocking the Un Security Council: The Uniting for Peace Resolution' (2013) 18 Journal of Conflict and Security Law p. 470.

160 White, supra note 149, p. 245. 
on the basis that Guatemala had recognized the government of Taiwan. ${ }^{161}$ In 1999, China blocked the extension of the United Nations Preventive Deployment Force ('UNPREDEP') to Macedonia for similar reasons. In the view of the Canadian representative, China's voting behaviour was "compelled by bilateral concerns unrelated to UNPREDEP" and thus "constitute[d] an unfortunate and inappropriate use of the veto." ${ }^{162}$ But also a concurring vote may violate the obligation to act in good faith. If, for example, a Council member voted in favour of a request by the Security Council for deferral of an investigation or prosecution according to Article 16 of the ICC Statute so that a person is unduly kept in custody without a trial, rather than with a view to the purposes laid down in Chapter viI of the Charter, ${ }^{163}$ this would amount to an abuse of power.

\subsubsection{Legal Limits Arising under Other Treaties}

Apart from the obligation arising under Article 2(2) of the UN Charter, the members of the Security Council are also bound by other international treaties ratified by them when voting in the Council. For example, Council members that are parties to the ICC Statute may not act contrary to its terms when exercising their voting rights in the Council. ${ }^{164}$ Similarly, human rights and humanitarian law treaties, such as the ICCPR, the ECHR, the Genocide Convention, ${ }^{165}$ and the Geneva Conventions, ${ }^{166}$ may require Council members to vote in a specific way on certain proposed resolutions.

As a general rule, human rights obligations are owed to all individuals subject to the jurisdiction of the state party concerned. ${ }^{167}$ With regard to the

161 UN Security Council, $5^{2^{\text {nd }}}$ Session, $373^{\text {th }}$ meeting (10 January 1997), UN Doc. S/PV.3730, p. 20. See Sievers and Daws, supra note 10, p. $35^{8}$.

162 UN Security Council, $54^{\text {th }}$ Session, $3982^{\text {nd }}$ meeting, 25 February 1999, UN Doc. s/PV.3982, p. 7 .

163 See Condorelli and Villalpando, supra note 109, p. 653 .

164 See Carsten Stahn, 'The Ambiguities of Security Council Resolution 1422 (2002)' (2003) 14 European Journal of International Law pp. 100-101, concerning the Security Council's deferral of potential prosecutions of peacekeepers.

1651948 Convention on the Prevention and Punishment of the Crime of Genocide, opened for signature 9 December 1948, 78 UnTs p. 277.

166 Convention (I) for the Amelioration of the Condition of the Wounded and Sick in Armed Forces in the Field, 12 August 1949, 75 UNTS p. 31; Convention (II) for the Amelioration of the Condition of Wounded, Sick and Shipwrecked Members of Armed Forces at Sea, $12 \mathrm{Au}-$ gust 1949, 75 UnTs p. 85; Convention (III) Relative to the Treatment of Prisoners of War, 12 August 1949, 75 UNTs p. 135; Convention (IV) Relative to the Protection of Civilian Persons in Time of War, 12 August 1949, 75 UnTS p. 287.

167 See e.g. ICCPR, Art 2(1); 1950 European Convention for the Protection of Human Rights and Fundamental Freedoms, opened for signature 4 November 1950, 213 UNTS p. 222, Art 1. 
ECHR, the ECtHR ruled in Matthews v. United Kingdom that its "Article 1 makes no distinction as to the type of rule or measure concerned, and does not exclude any part of the member States' 'jurisdiction' from scrutiny under the Convention."168 The Court held that a decision of the Council of the European Communities constituted an international instrument that was freely entered into by the United Kingdom, so that the United Kingdom was responsible for its consequences. ${ }^{169}$ Thus, unlike as is the case with acts that a state is obliged to adopt due to its membership of an international organization, ${ }^{170}$ a state is responsible under Article 1 of the ECHR for the consequences of its voting behaviour in an international body such as the Council of the European Communities and thus bound by the substantive obligations of the ECHR. ${ }^{171}$ The Court confirmed this view in the Segi case. There, it stated that by taking part in the preparation and adoption of Common Foreign and Security Policy ('CF SP') decisions, which are taken by unanimity or qualified majority, each EU member state engages its responsibility. ${ }^{172}$ In our view, the same must apply with regard to the voting behaviour in the Security Council. ${ }^{173}$ Furthermore, there is no apparent reason why states should not be equally bound under human rights treaties other than the ECHR. ${ }^{174}$

168 Matthews v. United Kingdom, 18 February 1999, European Court of Human Rights, App. No 24833/94, Reports of Judgments and Decisions 1999-I, pp. 251, 265.

169 Ibid., p. 266.

170 See Bosphorus v. Ireland, 30 June 2005, European Court of Human Rights, App. No 45036/98, Reports of Judgments and Decisions 2005-VI, pp. 107, 142, 158-159.

171 Theodor Schilling, 'Der Schutz der Menschenrechte gegen Beschlüsse des Sicherheitsrats' (2004) 64 Zeitschrift für ausländisches öffentliches Recht und Völkerrecht p. 346.

172 Segi and others v. 15 States of the European Union, 23 May 2002, European Court of $\mathrm{Hu}-$ man Rights, App. Nos 6422/02 and 9916/o2, Reports of Judgments and Decisions 2002-V, pp. 371, 378 .

173 Accordingly, the Committee on Economic, Social and Cultural Rights has reminded the members of the Security Council, when deciding on the imposition of economic sanctions through the Council, to take account of their duty under Art 2(1) of the International Covenant on Economic, Social and Cultural Rights ('ICESCR') to take steps to achieve progressively the full realization of the rights recognized in the Covenant: Committee on Economic, Social and Cultural Rights, General Comment No 8: The Relationship between Economic Sanctions and Respect for Economic, Social and Cultural Rights (12 December 1997), UN Doc. E/C.12/1997/8, para. 8.

174 This has been accepted by the Committee on Economic, Social and Cultural Rights with regard to the ICESCR. In addition to the observation referred to in supra note 173, the Committee has repeatedly pointed out that states parties of the ICESCR have an obligation to ensure that their actions as members of international organizations (in particular international financial institutions) take due account of the rights guaranteed 
Article 103 of the UN Charter does not constitute an obstacle to the voting behaviour in the Security Council being subject to obligations under human rights treaties. Article 103 only concerns the situation where there is a conflict between member states' obligations under the Charter and their obligations under human rights treaties. Yet, while such a conflict may arise as a consequence of the adoption of a legally binding Security Council resolution, there is no conflict prior to its adoption, including at the voting stage where Council members have discretion as to how to vote. ${ }^{175}$ The ECtHR, in contrast, held in Behrami and Saramati that the vote of a permanent member of the Council in favour of the Chapter viI resolution at issue was not subject to its scrutiny. The Court argued that if it were to adjudicate on the legality of votes in favour of a particular Council resolution, it would hamper the effective conduct of the United Nations' operations and interfere with its mission to secure international peace and security. ${ }^{176}$ This finding, however, is not convincing. It cannot be reconciled with the Court's previous jurisprudence concerning the responsibility of member states of an international organization ${ }^{177}$ and is not supported by any legal explanation but only some unspecified assumptions about the alleged negative impact of human rights obligations on the effectiveness of the system of collective security. ${ }^{178}$

The obligations that may arise under human rights and humanitarian law treaties with regard to the voting behaviour are manifold. For instance, Council members are required to vote against a Security Council resolution that

by the ICESCR: Committee on Economic, Social and Cultural Rights, General Comment No 14: The Right to the Highest Attainable Standard of Health (11 August 2000), UN Doc. E/C.12/200o/4, para. 39; General Comment No 15: The Right to Water (20 January 2003), UN Doc. E/C.12/2002/11, para. 36; General Comment No 18: The Right to Work (6 February 2006), Un Doc. E/C.12/GC/18, para. 30; General Comment No 19: The Right to Social Security (4 February 2008), UN Doc. E/C.12/GC 19, para. 58.

175 Andreas Zimmermann, 'Article 27' in Bruno Simma et al. (eds), The Charter of the United Nations: A Commentary ( $3^{\text {rd }}$ ed) (Oxford University Press, Oxford, 2012) p. 871, para. 64 ('Zimmermann, Article 27 Un Charter').

${ }_{176}$ Behrami and Behrami v. France, Saramati v. France, Germany and Norway, 2 May 2007, European Court of Human Rights, App. Nos 71412/01 and 78166/o1, para. 149.

177 Murray, supra note 158, p. 306; Pasquale De Sena and Maria Chiara Vitucci, "The European Courts and the Security Council: Between Dédoublement Fonctionnel and Balancing of Values' (2009) 20 European Journal of International Law pp. 218-221.

178 Christoph Grabenwarter and Katharina Pabel, Europäische Menschenrechtskonvention: Ein Studienbuch ( $5^{\text {th }}$ ed) (Helbing Lichtenhahn, Basel, 2012) pp. 116-117; Zimmermann, Article 27 UN Charter, supra note 175, para. 64; de Sena and Vitucci, supra note 177, pp. 204-206. 
grants UN forces blanket powers and absolves them from complying with human rights guarantees. ${ }^{179}$ Similarly, when the Council establishes a system of targeted sanctions, Council members are obliged to use their vote in a way that ensures that the necessary substantive and procedural safeguards for the protection of human rights are built into the system. ${ }^{180}$ The members of such a sanctions committee of the Security Council may have to vote against the listing of certain individuals or, conversely, in favour of their delisting. ${ }^{181} \mathrm{Fi}$ nally, it may be argued that Council members are under an obligation to vote in favour of (or at least not against) a resolution authorizing action that would be able to prevent, or bring an end to, genocide, crimes against humanity, or war crimes. ${ }^{182}$

\subsection{Legal Review of States' Voting Behaviour in the Security Council}

The voting behaviour of the members of the Security Council can be reviewed for its compliance with the legal limits set out in Section 2.3 in a number of different ways.

There is, first of all, the possibility of a review by the ICJ. The General Assembly or the Security Council itself can request an advisory opinion from the Court on the question of whether a vote in the Council amounts to a violation of international law. Undoubtedly, this constitutes a legal question in the sense of Article 96 of the Charter. ${ }^{183}$

Furthermore, the ICJ has confirmed that contentious proceedings can be brought against a state for its participation in the decision-making process of NATO. ${ }^{184}$ There is no reason why the same should not apply with regard to the UN Security Council. Thus, a state can institute contentious proceedings before the Court against a Council member, claiming that a vote cast by that member does not comply with the legal limits explained above or even trying to prevent it from voting in a specific manner. ${ }^{185}$ This is, in fact, exactly what

179 Schilling, supra note 171, pp. 349-356.

180 Parliamentary Assembly of the Council of Europe, Resolution 1597 (23 January 2008), $5^{\text {th }}$ Session, Doc. 11454, para. 7.2; Iain Cameron, The European Convention on Human Rights, Due Process and United Nations Security Council Counter-Terrorism Sanctions, Report prepared for the Council of Europe, 6 February 2006, pp. 27-28.

181 De Sena and Vitucci, supra note 177, pp. 227-228.

182 See infra Section 3.2.

183 Spiropoulos, supra note 153, pp. 9-10.

184 Application of the Interim Accord of 13 September 1995 (The Former Yugoslav Republic of Macedonia v. Greece), 5 December 2011, International Court of Justice, Judgment, [2011] ICJ Rep p. 644, paras. 39-44.

185 Martenczuk, supra note 66, pp. 77-78. 
Libya did in the Lockerbie case: Libya requested the ICJ to adopt provisional measures against the United Kingdom and the United States, arguing that such measures were urgently required to refrain them "from taking any initiative within the Security Council for the purpose of impairing that right to exercise jurisdiction, which Libya asks the Court to recognize."186 Once Security Council Resolution 748 had been adopted, Libya claimed that "the United Kingdom and the United States should so act as not to infringe Libya's rights, for example by seeking a suspension of the relevant part of Resolution 748 (1992)."187 However, the Court never addressed the substance of these claims. Similarly, in 1993 Bosnia and Herzegovina notified the ICJ in writing that it intended to institute proceedings against the United Kingdom for complicity in genocide, on the grounds that the United Kingdom had opposed efforts of other members in the Security Council to lift the arms embargo imposed on Bosnia and Herzegovina. Bosnia and Herzegovina later dropped its plan to lodge the complaint, apparently in response to a pledge by the United Kingdom to increase humanitarian aid and to promote a negotiated political settlement. ${ }^{188}$

With specific regard to obligations under human rights treaties, the $s u$ pervisory bodies established by these treaties (such as the UN Human Rights Committee and the ECtHR) can review the voting behaviour of those Security Council members that are parties to the respective treaty for compliance with the obligations under that treaty. This can occur, first, in the context of state reporting procedures, as far as the respective human rights treaty provides for such a procedure. ${ }^{189}$ Second, a state party to a human rights treaty could bring

186 Questions of Interpretation and Application of the 1971 Montreal Convention arising from the Aerial Incident at Lockerbie (Libyan Arab Jamahiriya v. U K), 14 April 1992, International Court of Justice, Provisional Measures, Order, [1992] ICJ Rep p. 3, dissenting opinion by Weeramantry, J. at pp. 12-13; Questions of Interpretation and Application of the 1971 Montreal Convention arising from the Aerial Incident at Lockerbie (Libyan Arab Jamahiriya v. US), 14 April 1992, International Court of Justice, Provisional Measures, Order, [1992] ICJ Rep p. 114, p. 124.

187 Questions of Interpretation and Application of the 1971 Montreal Convention arising from the Aerial Incident at Lockerbie (Libyan Arab Jamahiriya v. U K), 14 April 1992, International Court of Justice, Provisional Measures, Order, [1992] ICJ Rep p. 3, dissenting opinion by Weeramantry, J. p. 14; Questions of Interpretation and Application of the 1971 Montreal Convention arising from the Aerial Incident at Lockerbie (Libyan Arab Jamahiriya v. Us), 14 April 1992, International Court of Justice, Provisional Measures, Order, [1992] ICJ Rep p. 114, p. 125 .

188 John Quigley, 'State Responsibility for Ethnic Cleansing' (1999) 32 University of California Davis Law Review pp. 375-377.

189 Schilling, supra note 171, pp. 357-358. 
an inter-state complaint against a Council member that is party to the same treaty, alleging that its vote in favour of a Security Council resolution that results in human rights violations breaches its obligation not to defeat the object and purpose of the treaty. ${ }^{190}$ Third—and, from a practical point of view, most importantly - a review of the voting behaviour is also possible in the context of an individual complaint. As a general rule, neither a Security Council resolution as such nor, therefore, votes contributing to its adoption can form the subject of an individual complaint: Security Council resolutions are typically not 'self-executing' (that is, they do not have a direct effect in domestic law) but need to be implemented by states, so that individuals will normally lack the victim status required to bring an individual complaint. ${ }^{191}$ What an individual can claim, however, is that a measure by a state party implementing a Security Council resolution violates the respective human rights treaty. If the state, at the time of the adoption of the resolution, had been a member of the Council and now tried to invoke Article 103 of the UN Charter as a justification for the implementing measure, the supervisory body would have to review its voting behaviour. If the state had voted in favour of the resolution, the obligation not to defeat the object and purpose of the human rights treaty would bar it from invoking Article 103 of the Charter. ${ }^{192}$

\subsection{Conclusion}

The Security Council does not operate in a legal vacuum. Neither is the Council completely free to act as it wants, nor are the Council members completely free to decide how to vote. Both (in)action of the Security Council as a collective body and the voting behaviour of its individual members are subject to legal limits. Compliance with these legal limits imposed on the Council and the members can be reviewed in various ways.

However, a meaningful legal review of the Security Council's acts (or omissions) and of the votes of its members is only possible if the reviewing body or entity knows the reasons for them. Not only what the Council decides must be subject to legal limits, but also how it decides. In Section 3 we will argue that, in certain situations, the Security Council and its members are already today obliged to give reasons for their decisions and votes, respectively. In Section 4 we sketch out a proposal to introduce, de lege ferenda, a comprehensive duty to explain in a public meeting every vote cast in the Security Council.

\footnotetext{
190 Ibid., pp. 358-359.

191 See Peters, Article 25 UN Charter, supra note 65, paras. 45-54, for a discussion of the direct effect of Security Council resolutions.

192 Schilling, supra note 171, pp. 359-36o.
} 
Providing explanations for decisions and votes would be in the best interest of the Council and its members themselves: without explanations, the reviewing body or entity will be more likely to come to the conclusion that the respective decisions or votes are not supported by sufficient reasons and are thus illegal.

A Duty to Give Reasons-De Lege Lata

In certain situations, there is already today, de lege lata, an obligation incumbent on the Security Council to give reasons for its decisions and, respectively, on its members to explain their votes in the Council, although this duty is not implemented. In particular, a duty to give reasons may arise, first, from the due process rights guaranteed by international human rights law (Section 3.1) and, second, from the responsibility to protect (Section 3.2).

\subsection{Due Process Rights under International Human Rights Law}

As part of the expansion of its scope of activity, the Security Council has started to adopt more and more measures that directly affect specific individuals, groups, or corporate entities. The Council thus increasingly assumes functions that are normally performed by courts or administrative bodies.

When the Council acts in a manner that directly affects important interests of non-state actors, the due process guarantees provided by international human rights law become applicable. As pointed out in Section 2.1, there are compelling reasons to assume that the Security Council is bound to respect human rights. This applies all the more so with regard to the rights building the focus of the present analysis, the rights to a fair hearing and an effective remedy. These rights belong to a universal minimum standard of due process which can be considered as forming part of customary international law and as also being protected by general principles of law in the meaning of Article $38(1)$ (c) of the ICJ Statute. 193

The right to be informed about the reasons for a decision affecting individual interests is one of the key due process rights under international human rights law. This right is rooted in the right to a fair hearing as it is guaranteed by Article 10 of the UDHR, Article 14(1) of the ICCPR, Article 6(1) of the ECHR, Article 8(1) of the American Convention on Human Rights ('ACHR'), ${ }^{194}$ and

\footnotetext{
193 Bardo Fassbender, Targeted Sanctions and Due Process, Study Commissioned by the UN Office of Legal Affairs, 20 March 2006, p. 15.

194 American Convention on Human Rights, opened for signature 22 November 1969, 1144 UNTS p. 123 .
} 
Article 7(1) of the African Charter of Human and Peoples' Rights ('ACHPR'). ${ }^{195}$ The right to a fair hearing does not only apply in criminal proceedings but in all proceedings concerning the determination of a person's "rights and obligations in a suit at law"196 or "civil rights and obligations", 197 which includes certain administrative proceedings. ${ }^{198}$ It requires decision-makers to "indicate with sufficient clarity the grounds on which they based their decision,"199 although not every point raised in argument must be dealt with. ${ }^{200}$ Only if a reasoned decision is given is it possible for the individual concerned to know that his or her arguments have been properly examined and to exercise any available right of appeal, and only then can the public scrutinize the administration of justice. ${ }^{201}$

The right to learn the reasons of a decision also follows from the right to have an effective remedy. Article 8 of the UDHR, Article 2(3) of the ICCPR, Article 13 of the ECHR, and Article 25 of the ACHR all provide that everyone whose rights have been violated shall have an effective remedy. A remedy may, however, only be characterized as 'effective' if the person concerned or, at the very least, the body that reviews the impugned act is informed about the reasons behind it; it is only possible to understand and review an act if one knows the reasons for it. ${ }^{202}$ Thus, the ECtHR has ruled that proceedings for reviewing a deportation order, in which the person concerned is only given an outline of the grounds for the deportation and the findings of the reviewing panel themselves are not disclosed, do not constitute an 'effective' remedy. ${ }^{203}$

195 African Charter on Human and Peoples' Rights, opened for signature 27 June 1981, 1520 UNTS p. 217.

196 ICCPR, Art 14(1).

197 ECHR, Art 6(1).

198 For the ICCPR, see UN Human Rights Committee, General Comment No 32 (23 August 2007), UN Doc. CCPR/C/GC/32, para. 16.

199 Hadjianastassiou v. Greece, 16 December 1992, European Court of Human Rights, App. No $12945 / 87,252$ ECtHR (Ser. A) p. 16.

200 Van de Hurk v. The Netherlands, 19 April 1994, European Court of Human Rights, App. No 16034/90, 288 ECtHR (Ser. A) p. 20.

201 Tatishvili v. Russia, 22 February 2007, European Court of Human Rights, App. No 1509/02, Reports of Judgments and Decisions 2007-I, pp. 175, 190-191. See generally Stefan Trechsel, Human Rights in Criminal Proceedings (Oxford University Press, Oxford, 2005) pp. 102-106 (discussing the meaning and function of the right to a reasoned judgment).

202 See e.g. Prosecutor v. Kunarac et al., 12 June 2002, International Criminal Tribunal for the Former Yugoslavia, Judgement, Case No IT-96-23 and 23/1-A, para. 41 (holding that the right to a reasoned opinion both enables the useful exercise of the right to appeal and allows the appellate body to review the findings made by the trial court).

203 Chahal v. United Kingdom, 15 November 1996, European Court of Human Rights, App. No 22414/93, Reports of Judgments and Decisions 1996-v, p. 1831, p. 1871. 
As far as the Security Council has assumed the role of a (criminal) court and created tribunals for the prosecution of persons responsible for serious violations of international humanitarian law, it has met its obligation to provide reasons for its decisions by transposing it on these tribunals. The statutes of the ICTY and the ICTR, which were adopted by resolutions of the Security Council, ${ }^{204}$ both provide that judgments must be accompanied by a reasoned opinion in writing, to which separate or dissenting opinions may be appended. ${ }^{205}$ Other decisions of the tribunals and orders of its judges must, as a general rule, equally be supported by reasons. ${ }^{206}$

The situation is different, however, as far as the Security Council, taking on the role of an administrative body, has adopted other measures that directly affect non-state actors. By far the most important of these are sanctions imposed by the Council that are targeted against specific individuals and non-state entities. ${ }^{207}$ Unlike as with the international criminal tribunals, the Council has so far failed to impose on its sanctions committees a duty to give reasons for their decisions.

There are currently 13 sanctions regimes imposed by the Security Council in place, each administered by its own sanctions committee, that is, a subsidiary body of the Council whose composition reflects its own. ${ }^{208}$ The oldest of the existing sanctions regimes, concerning Somalia, was established in $1992^{209}$ and the most recent, concerning South Sudan, in 2015. ${ }^{210}$ All of these regimes are designed to, among other things, designate specific individuals and non-state

204 UN Security Council, Resolution 827 (25 May 1993), Un Doc. s/Res/827, para. 2; Un Security Council, Resolution 955 (8 November 1994), UN Doc. S/RES/955, para. 1.

205 Statute of the International Criminal Tribunal for Rwanda, UN Security Council Resolution 955 (8 November 1994), Un Doc. S/RES/955 ('ICTR Statute'), Art 22(2); Statute of the International Criminal Tribunal for the former Yugoslavia, UN Security Council Resolution 827 (25 May 1993), un Doc. S/Res/827 ('ICTY Statute'), Art 23(2). See also ICTR Rules of Procedure and Evidence (29 June 1995), un Doc. ITR/3/REv.23, Rules 88(C) and 118(B); and, respectively, ICTY Rules of Procedure and Evidence (14 March 1994), UN Doc. IT/32/ Rev. 49, Rules 98 ter(C) and 117 (B).

206 See e.g. ICTR Rules of Procedure and Evidence, Rules 13, 40bis (D), 79(B); ICTY Rules of Procedure and Evidence, Rules 13, 4obis(C), 79(B).

207 Another example of measures belonging into this category are resolutions of the Security Council that request the extradition of suspected terrorists. See de Wet, supra note 37, pp. 348-351.

208 See supra note 44 for the list of UN Security Council Sanctions Committees.

209 UN Security Council Resolution 751 (24 April 1992), UN Doc. S/RES/751.

210 UN Security Council Resolution 2206 (3 March 2015), UN Doc. s/RES/2206, para. 16. 
entities as targets of sanctions, ${ }^{211}$ although in the case of one regime no one has actually been placed on the list so far. ${ }^{212}$ Usually, the measures imposed on the listed individuals and entities include a travel ban, an assets freeze, and an arms embargo.

In the case of most sanctions regimes, the listed individuals and entities are linked to the government of a country. This is not the case, however, with the sanctions regime established according to Security Council Resolution 1267 of 1999, which targets individuals and entities belonging to, or associated with, Al-Qaida and/or the Taliban. ${ }^{213}$ Due to the high number of individuals and entities subject to it, this sanctions regime, often simply referred to as 'the terrorist sanctions regime', has attracted the greatest attention. ${ }^{214}$

Given the great variety of sanctions regimes and the differences in the procedures that are applicable before them, it is difficult to make generalized statements about the compatibility of targeted sanctions with human rights guarantees. In particular, this will depend to a considerable extent on the nature of the sanctions that are imposed on a given individual or entity. In certain cases, the effects of including a person or entity on a sanctions list may be sufficiently serious to amount to the determination of a "criminal charge", triggering the fair hearing guarantees listed above. ${ }^{215}$ Even if such a qualification is rejected, these guarantees will in most cases be applicable on the basis that listing concerns the determination of "rights and obligations in a suit at law" or "civil rights", respectively, as the placing of a person on a publicly available sanctions list can be said to amount to an attack on his or her reputation and/or may entail an interference with property rights. ${ }^{216}$ Thus, the respective sanctions committee would have to provide a fair hearing, which, as explained above, includes the right to be informed about the reasons for a decision, in the present context the reasons for the listing. Even if one was to conclude that the guarantee of a fair hearing does not apply to targeted sanctions, listed individuals or entities would still have the right to an effective remedy against

211 See for the compendium of UN sanctions lists: Consolidated United Nations Security Council Sanctions List, UN Security Council Sanctions Committees, available at: <https:// www.un.org/sc/suborg/en/sanctions/un-sc-consolidated-list>.

212 This is the case with the sanctions regime established pursuant to UN Security Council Resolution 1636 (31 October 2005), UN Doc. s/REs/1636.

213 The Al-Qaida and Taliban Sanctions Committee was split into two separate committees in 2011. UN Security Council Resolution 1988 (17 June 2011), Un Doc. S/RES/1988; Un Security Council Resolution 1989 (17 June 2011), UN Doc. S/RES/1989.

214 See Johnstone, supra note 9, p. 295.

215 See e.g. Cameron, supra note 180, p. 10; de Wet, supra note 37, p. 353.

216 See e.g. Cameron, supra note 180, p. 12. 
the listing and its consequences. Any such remedy can only be qualified as 'effective', if the sanctions committee informs the reviewing body of the reasons that led to the listing, although these reasons must not necessarily be made publicly available. ${ }^{217}$

In short, when the Security Council establishes sanctions committees it should - just as it did in the case of the international criminal tribunalsimpose on them a duty to give reasons for their listing decisions. There are two basic formats in which this duty can be implemented. Either the individual committee members are obliged to explain their positions with regard to the listing of individuals or entities in the committee meetings and the records of these meetings are made available to the public (or, at the very least, to the parties concerned). Or the respective sanctions committee, acting as a collective body, provides reasons in writing for its listing decisions.

As explained in Section 1 above, neither has happened. The procedures of the sanctions committees are notoriously obscure. The committees mostly meet in informal consultations, which are not recorded. As far as formal meetings are held at all, they take place almost entirely behind closed doors, with their records not being published. None of the sanctions committees directly informs the individuals and entities concerned of their listing, let alone of the reasons for the listing. In 2009, the Security Council at least directed the 1267 Committee to make accessible on its website 'narrative summaries of reasons for listing' the respective individuals and entities, which are mainly based on information provided by the designating state(s). ${ }^{218}$ Some other committees now also publish such 'narrative summaries'. Nevertheless, the sanctions committees are still not obliged to publish fully reasoned decisions specifying the supporting evidence.

This has, accordingly, been criticized by a number of courts in the context of the review of measures implementing Security Council resolutions, referred to in Section 2.2.1. The ECJ, in Kadiand Al Barakaat, observed with regard to the Al Qaida/Taliban sanctions regime that the 1267 Committee was not required to inform the designated persons or entities of the reasons for listing them or refusing to delist them. ${ }^{219}$ However, communication of the grounds for inclusion

217 Ibid., pp. 19-20.

218 See the information provided in United Nations Security Council Subsidiary Organs, Narrative Summaries of Reasons for Listing, available at: <https://www.un.org/sc/suborg/en/ sanctions/narrative-summaries>, select Sanctions Committee 'Security Council Committee pursuant to Resolutions 1267 (1999), 1989 (2011) and 2253 (2015) concerning ISIL (Da'esh) Al-Qaida and associated individuals groups undertakings and entities'.

219 Kadi and Al Barakaat Int'l Found. v. Council, 3 September 2008, European Court of Justice, Joined Cases C-402/05 P and C-415/05 P, ECR I-06351, para. 325 . 
on the list was required, first, so that the listed person could defend their rights in the best possible conditions and decide whether to bring legal proceedings and, second, in order to put the reviewing body fully in a position in which it may carry out the review of the lawfulness of the implementing measure. ${ }^{220}$ The ECJ concluded that the right to be heard and the right to effective judicial review enshrined in Articles 6 and 13 of the ECHR ${ }^{221}$ "were patently not respected". ${ }^{222}$ With regard to the Iraqi sanctions system, the ECtHR has ruled that those subject to an assets freeze as a consequence of their inclusion on the list established pursuant to Security Council Resolution 1483 are entitled, in accordance with Article 6 of the ECHR, to have access to a court that has the power to verify whether their inclusion on the list was arbitrary. ${ }^{223}$ This would seem to imply a duty on behalf of the Sanctions Committee to give reasons for the listing, as otherwise a meaningful court challenge would not be possible. ${ }^{224}$ Finally, the Parliamentary Assembly of the Council of Europe has passed a resolution stating that targeted sanctions imposed by the Security Council such as freezing of assets and travel restrictions must meet "minimum procedural standards under the rule of law", which include "the right for everyone to be notified promptly and fully informed of the charges held against himself or herself, and of the decision taken and the reasons for that decision". ${ }^{225}$ The Parliamentary Assembly strongly deplored that the individual or entity concerned "is usually neither informed of the request, nor given the possibility to be heard, nor even necessarily informed about the decision taken."226

\subsection{Responsibility to Protect}

Apart from the due process guarantees under international human rights law, also the so-called 'responsibility to protect' ('R2P') gives rise to an obligation of the Security Council to explain its decisions and of its members to give reasons for their voting behaviour.

The concept of R2P was developed by the International Commission on Intervention and State Sovereignty ('ICISs'), which was established by the Canadian government. In its report of 2001, the ICISs set out the two building

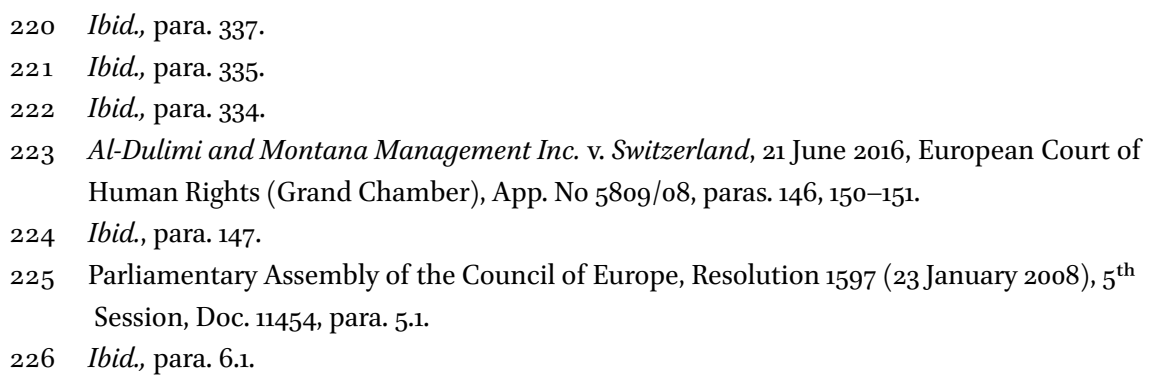


blocks of the concept. ${ }^{227}$ The first element is that state sovereignty implies responsibility, and the primary responsibility to protect populations lies with the territorial state. Second, however, "[w] here a population is suffering serious harm ... and the state in question is unwilling or unable to halt or avert it, the principle of non-intervention yields to the international responsibility to protect." 228 The most important expression of a recognition of R2P by states is the General Assembly's World Summit Outcome Document of 2005, in which the heads of state and government declared that

we are prepared to take collective action, in a timely and decisive manner, through the Security Council, in accordance with the Charter, including Chapter VII, on a case-by-case basis and in cooperation with relevant regional organizations as appropriate, should peaceful means be inadequate and national authorities are manifestly failing to protect their populations from genocide, war crimes, ethnic cleansing and crimes against humanity. 229

The World Summit Outcome Document is also significant in that it limits the scope of R2P as it was originally set out by the ICISS to the core international crimes as defined in Articles 6 to 8 of the ICC Statute-that is, genocide, war crimes, and crimes against humanity (including ethnic cleansing).

The legal nature of R2P is contentious. While some states find it to be a "sophisticated normative legal framework based on international law",230 others describe it as a "political commitment". ${ }^{231}$ The High-level Panel Report on Threats, Challenges and Change characterized R2P, and the corresponding obligation of the Security Council to take action in certain situations, as an "emerging norm". ${ }^{232}$ Given that the concept of R2P rose so quickly and is still in a state of flux, one can probably not confidently say much more about its legal nature than to point out that "the concept currently encompasses a spectrum of different normative propositions that vary considerably in their status and

227 International Commission on Intervention and State Sovereignty ('ICISs'), The Responsibility to Protect, 2001, Un Doc. A/57/303 (2002) ('ICISs Report').

228 Ibid., para. XI.

229 UN General Assembly, Resolution 6o/1 (24 October 2005), UN Doc. A/REs/6o/1, para. 139.

230 UN General Assembly, 63 ${ }^{\text {rd }}$ Session, $98^{\text {th }}$ plenary meeting (24 July 2009), UN Doc. A/63/PV.98, p. 26 (Canada).

231 UN General Assembly, 63 ${ }^{\text {rd }}$ Session, $97^{\text {th }}$ plenary meeting (23 July 2009), UN Doc. A/63/PV.97, p. 22 (Liechtenstein).

232 High-level Panel on Threats, Challenges and Change, A More Secure World: Our Shared Responsibility (2 December 2004), un Doc. A/59/565 ('High-level Panel Report'), para. 57. 
degree of legal support."233 One proposition that finds very broad support is that the host state has the responsibility to protect populations on its territory from large-scale atrocities. ${ }^{234}$ Much more controversial is the proposition that the United Nations, acting through the Security Council, or other states have a positive obligation to intervene to protect populations under the concept of R2P.

The position that such an obligation is incumbent on the Security Council relies, first of all, on the premise that the Council is subject to certain legal limits, which, as explained in Section 2.1, notably include human rights. As also explained in that Section, not only the Council's actions but also its omissions may be illegal: in certain situations, the Council is under a legal obligation to act. With regard to R2P this means that it could be argued that failure of the Security Council to authorize an intervention capable of protecting a population from core crimes, such as genocide, constitutes an illegal act, triggering the responsibility of the United Nations. ${ }^{235}$

In support of the proposition that other states have a positive obligation to intervene in R2P situations, one may point out that virtually all states of the world are parties to the four Geneva Conventions and the great majority of states, including nearly all current Security Council members, ${ }^{236}$ are parties to the Genocide Convention. These treaties, which address two of the three categories of core crimes in which the concept of R2P is rooted, contain provisions that are aimed at the prevention of their violation by other states. ${ }^{237}$ The obligation incumbent on states parties to the Genocide Convention under Article 1 to prevent genocide does not presuppose a territorial link $\mathrm{k}^{238}$ and will

233 Carsten Stahn, 'Responsibility to Protect: Political Rhetoric or Emerging Legal Norm?' (2007) 101 American Journal of International Law p. 102.

234 See ibid., p. 118.

235 See Christopher Verlage, Responsibility to Protect: Ein neuer Ansatz im Völkerrecht zur Verhinderung von Völkermord, Kriegsverbrechen und Verbrechen gegen die Menschlichkeit (Mohr Siebeck, Tübingen, 2009) pp. 246-250; Andreas Zimmermann, 'The Obligation to Prevent Genocide: Towards a General Responsibility to Protect?' in Ulrich Fastenrath et al. (eds), From Bilateralism to Community Interest: Essays in Honour of Bruno Simma (Oxford University Press, Oxford, 2011) p. 629, at pp. 638-643 (arguing for an obligation of the Security Council to counter situations of genocide, crimes against humanity, and war crimes); Peters, Spelling Out, supra note 146, pp. 305-311.

236 The two exceptions are Angola and Japan.

237 There is no corresponding general treaty-based obligation to prevent crimes against humanity extraterritorially. See Zimmermann, supra note 235, pp. 634-635.

238 Application of the Convention on the Prevention and Punishment of the Crime of Genocide (Bosnia and Herzegovina v. Serbia and Montenegro), 26 February 2007, International Court of Justice, Judgment, [2007] ICJ Rep p. 43, para. 430. 
be violated if, in the words of the ICJ, "the State manifestly failed to take all measures to prevent genocide which were within its power, and which might have contributed to preventing the genocide." ${ }^{239}$ Common Article 1 of the Geneva Conventions similarly obliges states parties "to respect and to ensure respect" for the Conventions, which means that every party "whether or not it is a party to a specific conflict, is under an obligation to ensure that the requirements of the instruments in question are complied with." 240 The precise content of this positive obligation is, however, rather unclear and may vary from one state to another depending on parameters such as the capacity to influence effectively persons likely to commit core crimes, the relationship with the host state, and the extent of the harm occurring. ${ }^{241}$ Furthermore, the obligation may not have to be (or even may not be) discharged unilaterally, but rather through multilateral efforts to protect.

For members of the Security Council, this obligation to engage in cooperative efforts to prevent core crimes could, in view of their special responsibility towards the international community, ${ }^{242}$ take the form of an obligation to vote in favour of a resolution authorizing an intervention. ${ }^{243}$ Accordingly, various states and international bodies have repeatedly called on the Council members, and especially the P5, not to block resolutions authorizing action designed to prevent, or bring an end to, mass atrocities. ${ }^{244}$

\section{Ibid.}

240 Legal Consequences of the Construction of a Wall in the Occupied Palestinian Territory, 9 July 2004, International Court of Justice, Advisory Opinion, [2004] ICJ Rep p. 136, para. 158.

241 Application of the Convention on the Prevention and Punishment of the Crime of Genocide (Bosnia and Herzegovina v. Serbia and Montenegro), 26 February 2007, International Court of Justice, Judgment, [2007] ICJ Rep p. 43, para. 430 (with regard to genocide). See Peters, Spelling Out, supra note 146, pp. 311-313.

242 See supra 2.3.

243 Peters, Spelling Out, supra note 146, p. 314.

244 See e.g. ICISs Report, supra note 227, p. $5^{1}$ (calling on the $\mathrm{P} 5$ to adopt a 'code of conduct' for the use of the veto with respect to actions that are needed to stop or avert a significant humanitarian crisis); High-level Panel Report, supra note 232, para. 256 (asking the P5 "to pledge themselves to refrain from the use of the veto in cases of genocide and large-scale human rights abuses"); UN Secretary-General, Implementing the Responsibility to Protect (12 January 2009), Un Doc. A/63/677, para. 26 (urging the P5 "to refrain from employing or threatening to employ the veto in situations of manifest failure to meet obligations relating to the responsibility to protect"); proposal for a General Assembly resolution by Costa Rica, Jordan, Liechtenstein, Singapore and Switzerland ('Small Five', or 's5'), revised version, un General Assembly Draft Resolution (15 May 2012), UN Doc. A/66/L.42/Rev.2, para. 20 (recommending the $\mathrm{P}_{5}$ to consider "[r]efraining from using a veto to block Council action aimed at preventing or ending genocide, war crimes and 
It would probably be premature to claim that this means that there is already now, de lege lata, a "hard and fast legal obligation" 245 on the Security Council to authorize an intervention every time an R2P situation arises and/ or on the members of the Council to vote in favour of a proposed resolution authorizing such an intervention. What can be confidently asserted, however, is that the Security Council and its members may not remain completely inactive in the face of genocide, war crimes, or crimes against humanity. Where a potential R2P situation arises, the Council and its members must at least convene a meeting, assess the situation, consider the different options, and, finally, "employ all means reasonably available"246 to prevent the commission of core crimes. ${ }^{247}$ Council members may not block a resolution aimed at protecting a population from core crimes without at least having considered the relevant facts and positions or merely based on political reasons that are not directly related to the R2P situation at issue. ${ }^{248}$

In other words, where there is evidence that core crimes are being committed, or are about to be committed, there exists a legal presumption that the Security Council and its members may not simply ignore these crimes but

crimes against humanity"); statement by the representative of France at the $67^{\text {th }}$ Session, $6870^{\text {th }}$ meeting of the Security Council (26 November 2012), UN Doc. S/PV.6870, p. 15 (proposal supporting the $\mathrm{P} 5$ "voluntarily and jointly foregoing the use of the veto in situations under the Council's consideration in which mass atrocities are being committed and, more generally, which pertain to the responsibility to protect"); Recommendation of the European Parliament (18 April 2013), 2012/2143(INI) (proposing that the P5 adopt "a voluntary code of conduct which would limit the use of the right of veto in cases of genocide, war crimes, ethnic cleansing or crimes against humanity"); statement by the representative of France at the $68^{\text {th }}$ Session, $705^{\text {nd }}$ meeting of the Security Council $(29$ October 2013), UN Doc. S/PV.7052, p. 13 (elaborating on the earlier French proposal by suggesting an alert mechanism to trigger the voluntary suspension of the veto right and suggesting that 50 Un member states should be allowed to challenge the Security Council when they believe mass atrocities have occurred); UN Security Council, $68^{\text {th }}$ Session, $7052^{\text {nd }}$ meeting (29 October 2013), UN Doc. S/PV.7052, p. 20 (encouragement of the Accountability, Coherence and Transparency Group ('ACT') — a cross-regional group of 22 states—- to the $\mathrm{P} 5$ to explore the proposal made by the Minister for Foreign Affairs for France, Mr. Laurent Fabius, "that the five permanent members themselves voluntarily regulate their right to exercise a veto in the case of mass atrocity crimes").

245 Peters, Spelling Out, supra note 146, p. 324.

246 Application of the Convention on the Prevention and Punishment of the Crime of Genocide (Bosnia and Herzegovina v. Serbia and Montenegro), 26 February 2007, International Court of Justice, Judgment, [2007] ICJ Rep p. 43, para. 430 (with regard to genocide).

247 Zimmermann, Article 27 UN Charter, supra note 175, para. 64.

248 Ibid., para. 65. 
must take some action to fulfil their responsibility to protect. ${ }^{249}$ The rise of the R2P concept has thus led to a reversal of the burden of justification: in R2P situations, not intervention but inaction must be justified. ${ }^{250}$ If a Council member votes against a proposed resolution authorizing intervention, it must state its reasons for doing so. Due to their power to block a Security Council decision on their own, a particularly strict obligation to explain their voting behaviour is incumbent on the permanent members, whereas the requirements with regard to explanations given by non-permanent members are somewhat relaxed. This procedural obligation is an indispensable component of the R2P concept. ${ }^{251}$ The perhaps most important merit of this concept is that it has developed a set of objective criteria to determine in which situations an intervention is called for and what standards it must meet. Only if the Council members are obliged to give reasons for their voting behaviour, is it possible to understand which of these criteria they think are (not) met and thus to assess whether the Security Council as an organ of the United Nations and its individual members live up to their responsibility to protect populations from core crimes.

A Duty to Give Reasons-De Lege Ferenda

In this last Section, we will first present the merits of a duty to give reasons for votes cast in the Security Council by elucidating the foundations this duty has in discourse theory and demonstrating the advantages it entails with regard to quality of decision-making, legal certainty, and accountability (Section 4.1). We shall then sketch out our proposal for a duty to give reasons and show how this duty could be implemented de lege ferenda (Section 4.2).

\section{1}

\section{The Merits of Reason-Giving}

4.1.1

Discourse Theory and the Rhetorical Community

Our proposal for a duty to give reasons for votes cast in the Security Council is based on a discourse theoretical approach that follows in the tradition of Jürgen Habermas's theory of communicative action. This theory did not only have a major impact in political science but, more recently, it has also been applied to the legal realm. ${ }^{252}$ We draw on these legal accounts to present the specific

\footnotetext{
249 Verlage, supra note 235, p. 253.

250 Ibid., pp. 250-253.

251 Peters, Spelling Out, supra note 146, p. 323.

252 See e.g. Robert Alexy, A Theory of Legal Argumentation: The Theory of Rational Discourse as Theory of Legal Justification (Ruth Adler and Neil MacCormick trans.) (Oxford University
} 
advantages of reason-giving in the context of the Security Council. In line with the discourse theoretical foundation of our approach, we adopt a constructivist view of international relations. We believe that the international sphere is, to a large extent, socially constructed, that is, created by intersubjective and institutionalized understandings. The identity, the interests, and therefore also the behaviour of states and other international actors are continuously shaped and reshaped by social practices such as discourse, persuasion, collective learning, socialization, institutionalization, etc. ${ }^{253}$ This approach is opposed to the realist view, according to which states are unitary actors that pursue their own national interests, which are characterized as being predetermined: formed without any social interaction with other actors in the international realm. ${ }^{254}$ In order to grasp the significance of discourse theory for the case we are making, it is first necessary to briefly outline Habermas's theory of communicative action.

Habermas's discourse theoretical approach is best understood as a late modern attempt to explain rationality. ${ }^{255}$ For Habermas, rationality is neither something objective nor something subjective, but rather the result of a continuous communicative process of forming, criticizing, and revising conclusions. In Habermas's view, the way rational conclusions can be reached is by uttering speech acts that imply specific validity claims (Geltungsansprüche). These validity claims are subject to the assessment by the participants of the

Press, Oxford, 1989); Samantha Besson and José L. Marti, 'Introduction' in Samantha Besson and José L Marti (eds), Deliberative Democracy and its Discontents (Ashgate Publishing, Aldershot, 2006) p. xiii;Jose E. Alvarez, 'Judging the Security Council' (1996) go American Journal of International Law p. 33; Mathilde Cohen, 'The Rule of Law as the Rule of Reasons' (2010) 96 Archiv für Rechts- und Sozialphilosophie p. 1; Ian Johnstone, 'Discursive Power in the UN Security Council' (2005) 2 Journal of International Law and International Relations p. 73 ('Discursive Power'); Ian Johnstone, 'Security Council Deliberations: The Power of the Better Argument' (2003) 14 European Journal of International Law p. 443 ('Security Council Deliberations'); Johnstone, supra note 9.

253 See Emanuel Adler, 'Constructivism in International Relations: Sources, Contributions and Debates' in Walter Carlsnaes et al. (eds), Handbook of International Relations (SAGE Publications, London, 2013) p. 112, and Ian Hurd, 'Constructivism' in Christian Reus-Smit and Duncan Snidal (eds), The Oxford Handbook of International Relations (Oxford University Press, Oxford, 2008) p. 298, for useful overviews of constructivism in international relations and further references.

254 See William C. Wohlforth, 'Realism' in Christian Reus-Smit and Duncan Snidal (eds), The Oxford Handbook of International Relations (Oxford University Press, Oxford, 2008) p. 131, for a short summary of the central tenets of realism.

255 See on this in detail Jürgen Habermas, The Philosophical Discourse of Modernity: Twelve Lectures (MIT Press, Cambridge MA, 1987). 
rational discourse. In this discourse, it is possible to influence other persons' actions if the claim one presents possesses sufficient rational force. ${ }^{256}$ In this sense, a discourse of the Habermasian type is an intersubjective forum for uttering, reviewing, and criticizing validity claims. ${ }^{257}$

How exactly should this discourse look like? In the ideal-type discursive situation that Habermas devises - the so-called "ideal speech situation"258_ all participants in the discourse have equal weight to make claims and assess and criticize others' arguments. In this ideal situation, all coercion must be eliminated so that only the "unforced force of the better argument" 259 prevails. The type of reasoning which, according to Habermas, should be used to find the better argument is communicative action. In contrast to instrumental and strategic action, which aim at a person's own success (solitarily in the case of instrumental action, socially by way of persuading others in the case of strategic action), communicative action is oriented towards reaching mutual understanding by exchanging arguments. ${ }^{260}$ Reasons, in this setting, play a crucial role because they allow persons to justify their claims to others. If the reasons are good enough, they may convince others of the argument and lead to an unforced consensus.

What is particularly important for the context of Security Council decisions is the fact that, in Habermas's theory, not only empirical statements can be vindicated in rational discourse but also commands and value judgments, ${ }^{261}$ which include normative claims. ${ }^{262}$ The claims made in and around the Security Council are of a predominantly political and legal nature and are rarely merely empirical. Because legal and political claims are generally normative claims, they can be vindicated in rational discourse. According to Habermas, this means that such legal and political claims can be found to be true, as long

256 Erik Oddvar Eriksen and Jarle Weigard, Understanding Habermas: Communicative Action and Deliberative Democracy (Bloomsbury, London, 2003) p. 4.

257 See Hugh Baxter, Habermas: The Discourse Theory of Law and Democracy (Stanford University Press, Stanford, 2011) p. 13.

258 Jürgen Habermas, Justification and Application: Remarks on Discourse Ethics (Ciaran Cronin trans.) (MIT Press, Cambridge MA, 1994) p. 56.

259 Jürgen Habermas, Between Facts and Norms: Contributions to a Discourse Theory of Law and Democracy (William Rehg trans.) (MIт Press, Cambridge MA, 1996) p. 306.

260 Jürgen Habermas, The Theory of Communicative Action: Volume One: Reason and the Rationalization of Society (Thomas McCarthy trans.) (Beacon Press, Boston MA, 1984) pp. 285-286.

261 Alexy, supra note 252, pp. 101-137; Habermas, supra note 259, p. 16.

262 See Jürgen Habermas, Legitimation Crisis (Thomas McCarthy trans.) (Heinemann, London, 1976) p. 105. See on this in detail Alexy, supra note 252, pp. 101-137. 
as we can engage in a discourse about them and are able to reach a consensus that is based on the best argument. ${ }^{263}$

This rough sketch of Habermas's theory of communicative action reveals that normative claims like the ones made in the Security Council can form the object of rational discourse. In this discourse, the claim supported with the best reasons will prove to be the better argument and will convince the participants. In our view, such a discursive environment in which people engage in the exchange of rational arguments is best described as a "rhetorical community". ${ }^{264}$ Depending on the nature of this community, different languages will be spoken. In the discourse in and around the Security Council, the languages that are primarily spoken are the languages of politics and law, although, for example, the language of morality can sometimes also play a role. These languages not only determine the conditions based on which actors may participate in the discourse but they also "establish ... roles and relations and voices, positions from which and audiences to which one may speak." 265 Each participant of the rhetorical community in and around the Security Council will propose certain political and/or legal claims and will support them with reasons. Depending on the strength of these reasons, other participants will (or will not) be convinced by the claims. In doing so, the participants in this rhetorical community shape and reshape the conclusions that are being drawn from the Council's political and legal framework.

A sceptic might question whether discourse theory can indeed be meaningfully applied to the realm of the Security Council. Is the Security Council not, above all, a forum for power politics and hence the very opposite of an ideal speech situation? The sceptic will point out that, contrary to the Habermasian ideal, not all members of the Security Council have the same access to the discourse. For example, the permanent members possess the veto power, which

263 See Jürgen Habermas, 'Wahrheitstheorien' in Helmut Fahrenbach (ed), Wirklichkeit und Reflexion: Walter Schulz zum 6o. Geburtstag (Neske, Pfullingen, 1973) pp. 211, 237-239.

264 We borrow this term from James B. White, When Words Lose Their Meaning: Constitutions and Reconstitutions of Language, Character, and Community (University of Chicago Press, Chicago IL, 1984) p. 246, who coined it in a literary context. See also Alvarez, supra note 252, p. 33 (discussing the term "rhetorical community" in the context of the UN Charter); Harald Müller, 'Internationale Bezeihungen als kommunikatives Handeln: Zur Kritik der utilitaristischen Handlungstheorien' (1994) 1 Zeitschrift für Internationale Beziehungen p. 33 (speaking of a "sense of community" which international law creates); Johnstone, Security Council Deliberations, supra note 252, p. 443 (referring to the concept of "interpretive community" of literary theorist Stanley Fish, which is similar to that of "rhetorical community" which we use).

265 White, supra note 264, p. 266. 
allows them to discard all non-procedural matters. ${ }^{266}$ Also, as explained in Section 1.1, some of the informal Security Council meetings, such as the 'Group of Friends' and the 'Contact Group', are only open to some of the Council members. For these reasons, deliberations in the Security Council are greatly unbalanced, so that, it could be argued, most (if not all) arguments based on discourse theory are bound to fail when it comes to the Security Council.

We do, of course, not deny the existence of asymmetries within the Security Council. However, we argue that the virtues of reason-giving also apply to speech situations that are not ideal. In fact, Habermas himself does not hold that real-life discourses could measure up to ideal speech situations. ${ }^{267}$ Instead, he points out that the idea of an ideal speech situation is a counterfactual standard that allows for the assessment of the quality of an argument. ${ }^{268}$ It is obvious that in real life, self-interest based arguments by powerful actors are ubiquitous. Yet this does not mean that arguments used in communicative action (that is, reasoned arguments) are completely absent in the debate. ${ }^{269}$ If such arguments are made at least to some extent, then critics are enabled to come into play and to point out that there is a gap between a participant's arguments and actions (this will later be discussed under the term 'discursive opening'). ${ }^{270}$ Thus, in order for our theory to get off the ground, it is sufficient that reasoned discourse takes place to a minimal extent.

As Ian Johnstone has pointed out, such a minimally reasoned exchange already exists in and around the Security Council today. ${ }^{271}$ What is necessary (and sufficient) for such a minimally reasoned debate to occur is "a sense of being in a relationship of some duration, from which common meanings and

\footnotetext{
266 Un Charter, Art 27(3).

267 Habermas, supra note 263, p. 257. See David Estlund, 'Democracy and the Real Speech Situation' in Samantha Besson and José L Marti (eds), Deliberative Democracy and its Discontents (Ashgate Publishing, Aldershot, 2006) pp. 75, 85 .

268 Jürgen Habermas, Zwischen Naturalismus und Religion: Philosophische Aufsätze (Suhrkamp, Frankfurt am Main, 2005) p. 91.

269 Thomas Risse and Kathryn Sikkink, 'The Socialization of International Human Rights Norms into Domestic Practices: Introduction' in Thomas Risse et al. (eds), The Power of Human Rights: International Norms and Domestic Change (Cambridge University Press, Cambridge, 1999) pp. 14-15.

270 See infra Section 4.1.2.1.

271 See Johnstone, Security Council Deliberations, supra note 252, pp. 456-457. See also ibid., p. 461 (highlighting that although relationships of power are present in the Security Council, there is also formal equality in that every member of the Security Council has one vote and the presidency rotates among all members. Furthermore, each member has the same right to put a matter on the Council's agenda).
} 
expectations have emerged, and of being engaged in an enterprise the general purpose of which all understand in roughly the same way."272 In the case of the Security Council, these common meanings and expectations derive from the legal limits set out in Section 2.1 above, in particular those contained in the UN Charter. This framework structures the debates in the Council, defining which arguments are acceptable or convincing and which ones are not. In the case of certain, particularly far-reaching resolutions, the Council has even found it necessary to render the process leading up to their adoption more open and inclusive, which "suggest[s] that a moderately inclusive deliberative process is not only possible but also understood to be necessary." 273 As a consequence, the decisions of the Security Council can, despite the existing asymmetries, be understood to result from the discursive processes that are taking place within and around the Council.

\subsubsection{Reasons for Giving Reasons}

Having thus rebutted the objection that reasoned discourse cannot occur in an imperfect speech setting such as the Security Council, we have set the stage for our argument in favour of a duty to give reasons for votes cast in the Council. The starting point for this argument is the fact that, when confronted with an audience, states will seek to justify their positions with reasons relating to common interests rather than merely with their own national interests. ${ }^{274} \mathrm{This}$ social norm is based on the assumption that actions which affect others will be justified with reasons that these others can endorse. ${ }^{275}$ In contrast, where states are not expected to explain their actions in public, as is the case with regard to decision-making in the Security Council and its committees at the moment, they are likely to base them on pure self-interest.

What can be gained from the fact that, according to the aforementioned social norm, states tend to give non-self-interested reasons when justifying their actions in public? What are the benefits of exposing the members of the Security Council to an open discourse in which they need to provide otherregarding reasons for their votes? In what follows, we will argue that a duty to give reasons in the Security Council has three major virtues. First, it will improve the quality of Security Council decisions. Second, it will lead to an

\footnotetext{
272 Ibid., p. 456.

273 Johnstone, supra note 9, p. 302.

274 See Oscar Schachter, 'International Law in Theory and Practice: General Course in Public International Law' (1982) 178 Receuil des Cours p. 59.

275 Jon Elster, 'Deliberation and Constitution Making' in Jon Elster (ed), Deliberative Democracy (Cambridge University Press, Cambridge, 1998) p. 97, p. 101.
} 
increase in legal certainty. And third, it will improve the accountability of the Security Council as a whole and of its members.

\subsubsection{Quality}

A duty to give reasons for votes cast in the Security Council will rationalize the Council's decision-making process and, ultimately, improve the quality of the adopted decisions. The reason for this is threefold. First, if decision-makers have to justify their decisions, they are more likely to exchange information and expertise, to carefully assess the available evidence, to weigh the different positions, and to reflect on their choices before making a decision. ${ }^{276}$ This allows them to be more successful at finding the decision that is best suited for the case at hand. ${ }^{277}$ Second, under a duty to give reasons, decision-makers are more likely to adopt reasonable decisions because they need to persuade others, including those most affected by the decisions. ${ }^{278}$ Since others will be able to examine and assess the justifications provided by the decision-maker, selfish and immoral arguments as well as arguments based on prejudice are likely to be suppressed. ${ }^{279}$ Thus, only a limited range of reasons can be invoked in order to justify decisions. In particular, decision-makers have fewer options to adopt decisions that are based on self-interested reasons. ${ }^{280}$ As Mathilde Cohen points out, "the duty to give reasons pushes decision-makers to pick the just outcomes." ${ }^{281}$ Third, decisions based on grounds that can be endorsed by others will in the long run lead to an improvement of decision-making in general. Future decision-makers are more likely to base their decisions on the non-self-interested reasons that antecedent decision-makers have given. ${ }^{282}$

It could be objected that, if members of the Security Council are obliged to provide reasons for their votes, they will simply give hypocritical reasons. In other words, they will pay lip service to the common good, while continuing

\footnotetext{
276 Cohen, supra note 252, p. 12.

277 Ibid., p. 13.

278 Ibid., p. 12; James Johnson, 'Arguing for Deliberation: Some Sceptical Considerations' in Jon Elster (ed) Deliberative Democracy (Cambridge University Press, Cambridge, 1998) p. 161, p. 171. See also Daniel Naurin, 'Does Publicity Purify Politics?' (2003) 12 Journal of Information Ethics p. 21 (referring to this phenomenon as "publicity's purifying effect").

279 Cass R. Sunstein, Democracy and the Problem of Free Speech (Free Press, New York, 1993) p. 244; Johnson, supra note 278, pp. 171-172; Naurin, supra note 278, p. 21.

28o Peters, Spelling Out, supra note 146, pp. 323-324; see Martti Koskenniemi, From Apology to Utopia: The Structure of International Legal Argument (Cambridge University Press, Cambridge, 2006) p. 67.

281 Cohen, supra note 252, p. 11.

282 Ibid., p. 13.
} 
to vote in a self-interested manner. If they start to 'talk the talk' of peace and international security, for example, they will merely do so for instrumental and strategic purposes. ${ }^{283}$ Therefore, the objection goes, a duty to give reasons will cause an increase in hypocrisy rather than an actual improvement of the quality of decisions.

This objection can be refuted by drawing on the notion of the so-called "civilizing force of hypocrisy". ${ }^{284}$ Jon Elster, who coined the term, argues that the fact that actors adopt impartial arguments-even if only for strategic reasonshas a beneficial effect because it exerts a civilizing force upon them. ${ }^{285}$ This civilizing force can be characterized as a two-stage process. At a first stage, states adjust to international pressures and public criticism by making some concessions and by beginning to 'talk the talk' that the public wants to hear, albeit only for instrumental or strategic reasons. They do so, not because they believe in the values they publicly support, but because they think that it will reduce those pressures and maximize their benefits. For example, a member of the Security Council may adopt a human rights-based explanation for its vote, although its real motives are purely strategic. Once states employ otherregarding language such as human rights, however, they enter the second stage. At this stage, a process of argumentative discourse in the Habermasian sense begins to take effect. Once states start to use impartial rather than self-interested arguments, that is, once they start to 'talk the talk' - even if in a merely hypocritical manner-they enter a discursive realm which is characterized by argumentation, persuasion, and criticism. ${ }^{286}$ By adopting arguments that are at odds with their practices, states create a "discursive opening". ${ }^{287}$ Once they give way to pressures and start to use arguments based

283 For what could, arguably, be understood to constitute an example of such 'talk', see Vladimir Putin, A Plea for Caution from Russia, N.y. Times, 11 September 2013, available at: <www.nytimes.com/2013/og/12/opinion/putin-plea-for-caution-from-russia-on-syria .html?_r=0 $>$.

284 Jon Elster, 'Strategic Uses of Argument' in Kenneth J. Arrow et al. (eds), Barriers to Conflict Resolution (W.W. Norton and Company, New York, 1995) p. 236, p. 250.

285 Elster, supra note 275, p. 111. See on the concept of the "civilizing force of hypocrisy" in detail Cohen, supra note 252, pp. 14-16, and Axel Gosseries, 'Publicity' in Edward N. Zalta (ed), The Stanford Encyclopedia of Philosophy (2010), available at: <plato.stanford.edu/ archives/fall2010/entries/publicity/>. Naurin, supra note 278, p. 27 correctly points out that the term "civilizing force of hypocrisy" is misleading because it suggests that it is hypocrisy itself which creates the positive effect on states' behaviour. In fact, however, the positive effect is caused by the social norms activated by publicity.

286 Risse and Sikkink, supra note 269, p. 13.

287 Johnstone, Security Council Deliberations, supra note 252, p. 454. 
on non-self-interested reasons to justify their decisions, their critics are able to step in and challenge them for not complying in practice with the standards and values they publicly endorse:288 "If you are really committed to stopping these massive human rights violations, then why do you veto the resolution?" This criticism can induce states to conform their policies to their public statements. ${ }^{289}$ To put it differently, what actors in the rhetorical community in and around the Security Council would start to do is to "cue"290 the (other) members of the Council by criticizing them for votes that are based on illegitimate reasons. Cueing is designed to induce them to adopt other reasons and to vote in conformity with the law and common values. ${ }^{291}$ This process of cueing or pointing the finger at other actors is, as José Alvarez observes, especially important on the international level, which-in contrast to the domestic level—is characterized by relatively few enforcement mechanisms. ${ }^{292}$ What is more, as Thomas Risse and Kathryn Sikkink argue, "the more [states] 'talk the talk' ... the more they entangle themselves in a ... discourse which they cannot escape in the long run". 293 This process of "self-entrapment" 294 may then be reinforced by a process of self-persuasion: over time, public officials may come to believe themselves in the policy positions they advocate in public. ${ }^{295} \mathrm{In}$ order to reduce cognitive dissonance, ${ }^{296}$ officials may eventually "begin believing in what they initially simply pretended they believed in."297

At this point, critics might intervene by questioning whether the psychological concepts of cognitive dissonance and self-persuasion can be transferred

288 See Thomas Risse, “Let's Argue!": Communicative Action in World Politics' (2000) 54 International Organization p. 22.

289 Johnstone, Security Council Deliberations, supra note 252, p. 454. See also Ryan Goodman and Derek Jinks, Socializing States: Promoting Human Rights Through International Law (Oxford University Press, Oxford, 2013) pp. 150-153 (referring to the studies conducted by Xinyuan in Xinyuan Dai, International Institutions and National Policies (Cambridge University Press, Cambridge, 2007) and O'Brien and Li in Kevin J. O'Brien and Li Lianjiang, Rightful Resistance in Rural China (Cambridge University Press, Cambridge, 2006)).

290 Alvarez, supra note 252, p. 30.

291 See ibid.pp. 30-1.

292 Ibid., p. 31.

293 Risse and Sikkink, supra note 269, p. 16.

294 Risse, supra note 288, p. 32.

295 See Risse and Sikkink, supra note 269, p. 15.

296 Naurin, supra note 278, p. 26. See Shelly Chaiken et al., 'Principles of Persuasion' in Edward T. Higgins and Arie W. Kruglanski (eds), Social Psychology: Handbook of Basic Principles (The Guildford Press, New York, 1996) pp. 702, 703-705 (on cognitive dissonance).

297 Cohen, supra note 252, p. 16. 
from human beings to states. ${ }^{298}$ In other words, what has been stated above might be correct for public officials, but does not suffice to explain a change in the behaviour of states. Ryan Goodman and Derek Jinks have presented a reply to this objection by pointing out that acculturation processes do not only occur in individuals but also in large-scale organizations like states. ${ }^{299}$ Macro-level developments (that is, developments on the international level such as the ratification of a human rights treaty), they argue, have an effect on micro-level developments by influencing relevant individual actors (for example government officials, NGO activists, journalists, or ordinary citizens). ${ }^{300}$ These individual actors, in turn, have an impact on the state's laws and policies. Hence, according to Goodman and Jinks, there is a "macro-micro-macro causal explanation"301 that accounts for the socialization of states. Following this explanation, we argue that through macro-micro-macro processes, an internalization of internationally shared values can also take place with regard to the member states of the Security Council. They, too, can come to believe their own impartial arguments and adapt their behaviour to public expectations. ${ }^{302}$ Thus, Council members can undergo a process of identity change in the sense that they will come to conceive of the once hypocritically adopted norms as the "normal thing to do". ${ }^{303}$

In summary, we argue that a duty to give reasons will lead Council members to justify their votes by invoking reasons that relate to common values (rather than their own interests) and that this will, in the long term, influence their voting behaviour and result in qualitatively better decisions.

\subsubsection{Legal Certainty}

Secondly, a duty to give reasons for votes cast in the Security Council will lead to an increase in legal certainty. Legal certainty is widely seen as constituting one of the primary pillars of the rule of law..$^{304}$ The rule of law requires that

298 See Johnson, supra note 278, pp. 172-173, for a similar criticism.

299 Goodman and Jinks, supra note 289 , p. 38.

300 Ibid., p. 40.

301 Ibid.

302 See Francisco J. Granados, 'Intertwined Cultural and Relational Environments of Organizations' (2005) 83 Social Forces p. 885.

303 Risse and Sikkink, supra note 269, p. 17.

304 James R. Maxeiner, 'Some Realism About Legal Certainty in the Globalization of the Rule of Law' in Mortimer Sellers and Tadeusz Tomaszewski (eds), The Rule of Law in Comparative Perspective: Ius Gentium: Comparative Perspectives on Law and Justice (Springer, Dordrecht, 2010) p. 41. 
laws and decisions are, in the words of the ECtHR, "sufficiently precise to allow the person ... to foresee, to a degree that is reasonable in the circumstances, the consequences which a given action may entail." ${ }^{305}$ In a similar vein, Cohen argues that people in legal systems ought to be able to "know in advance and in stable and general terms what is required by the law so that they can organize their life accordingly", adding that "[i]f law is to bind people, they must be able, without undue difficulty, to find out what it is." ${ }^{306}$ Without knowing the reasons for a law or a decision, however, it is difficult, if not impossible, to understand its content. Thus, reason-giving may be characterized as "one of the essential properties of the concept of the rule of law, if not the essential one." 307

Accordingly, legal systems that are based on the rule of law, including those of international organizations, typically prescribe a duty to give reasons. Article 296(2) of the Treaty on the Functioning of the European Union ('TFEU'), ${ }^{308}$ for example, stipulates: "Legal acts shall state the reasons on which they are based and shall refer to any proposals, initiatives, recommendations, requests or opinions required by the Treaties." In a case that touched on Article 296(2) TFEU, the ECJ-in line with the aforementioned jurisprudence of the ECtHR - argued that statements of reasons "must disclose in a clear and unequivocal fashion the reasoning followed by the institution which adopted that measure in such a way as to enable the persons concerned to ascertain the reasons for it." 309

Despite the fact that the Security Council is a highly political body, it is, as has been pointed out in Section 2.1 above, subject to the rule of law. The paradigm of legal certainty therefore also applies in the context of the Security Council. The states, non-state entities, and individuals affected by a given decision of the Security Council (or one of its committees) must be able to understand what it requires of them and what consequences non-compliance may entail. Forcing the Council members to submit reasons for their voting behaviour and thus to provide substantive information will allow the affected actors to assess more accurately the content of a specific decision. Knowing

305 Čalovskis v. Latvia, 24 July 2014, European Court of Human Rights, App. No 22205/13, para. 182.

306 Cohen, supra note 252, p. 7 .

307 Ibid., p. 3 .

308 Consolidated Version of the Treaty on the Functioning of the European Union (TFEU), 13 December 2007, 2008 oJ C 115/47.

309 Nexans SA and Nexans France SAS v. Commission, 14 November 2012, European Court of Justice, Case C-37/13 P, 2014, para. 31. 
the reasons behind a decision will, in turn, allow them to forecast with more precision what decisions the Security Council is going to adopt in the future. In this sense, reason-giving can be seen as a remedy for the epistemic deficits that result from the lack of transparency that, as explained in Section 1, currently characterizes Security Council deliberations. ${ }^{310}$

Thus, requiring members of the Security Council to disclose the reasons for their voting behaviour will increase legal certainty and thereby also compliance with the rule of law.

\subsubsection{Accountability}

A duty to give reasons will, lastly, improve the accountability of the Security Council and its members. The most widely accepted understanding of the concept of accountability - its 'core sense'-associates it with "the process of being called 'to account' to some authority for one's actions", 311 which entails some form of oversight and control. ${ }^{312}$

Although there is no final arbiter of actions of the Security Council, there is a range of different actors to which the Council may be called to account for its decisions and the Council members for their voting behaviour. As explained in Section 2, courts or quasi-judicial bodies that can engage in a legal review of Security Council action or of votes cast in the Council include the ICJ, the international criminal tribunals, the ICC, the ECtHR, the ECJ, the Un Human Rights Committee, and domestic courts. In addition, also non-judicial entities such as the General Assembly, regional organizations, and the UN member states scrutinize Security Council action for its conformity with international law. Furthermore, there are lawyers, representatives of NGOs, and ordinary citizens who take part in the rhetorical community around the Security Council. ${ }^{313}$ The languages of law and politics provide the entirety of this community with the tools for reviewing and assessing what the Security Council members decide. The rhetorical community engages the Council in "an ongoing dialogue, an 'expressive' mode of review". ${ }^{314}$

\footnotetext{
310 See Cohen, supra note 252, p. 7 .

311 Richard Mulgan, “Accountability”: An Ever-Expanding Concept?' (2000) 78 Public Administration p. 555 .

312 Tzanakopoulos, supra note 70, p. 4; Christian Henderson, 'Authority without Accountability? The UN Security Council's Authorization Method and Institutional Mechanisms of Accountability' (2014) 19Journal of Conflict and Security Law p. 492.

313 Johnstone, Discursive Power, supra note 252, pp. 79, 91. See also Johnstone, supra note 9, p. 301 (where he refers to this community as a 'public sphere' that evolves around the Security Council).

314 Alvarez, supra note 252, p. 28.
} 
Accountability requires transparency with regard to decision-making. This holds especially true for the decision-making organ of an international organization on which not all members are represented, such as the Security Council. In its report on the accountability of international organizations, the International Law Association ('ILA') observed that "[n]on-plenary organs acting on behalf of the whole membership under the governing provisions of an IO [international organization] have a special obligation to act as transparently as possible" and should hold their meetings, in principle, in public. ${ }^{315}$ Likewise, the reasons for the positions adopted by the states represented in that organ must be transparent. The ILA report therefore includes as one of the key requirements to achieve effective accountability that "organs of an Io should state the reasons for their decisions or particular courses of action whenever necessary for the assessment of their proper functioning or otherwise relevant from the point of view of their accountability."316

A duty to give reasons for votes cast in the Security Council is a necessary prerequisite for the meaningful exercise of the various ways of controlling and holding accountable the Council and its members. Those affected by a decision of (or a vote in) the Security Council can only effectively examine and, if necessary, contest it, if they know the reasons that have led to its adoption. Equally, it will, as a general rule, be inevitable for the body charged with reviewing a decision or voting behaviour to know its rationales in order to be able to assess its conformity with international law.

This holds even more true for decisions of the Security Council (and its subsidiary bodies) than for those of other international organs. Security Council resolutions are typically drafted in haste and under considerable political pressure. ${ }^{317}$ Accordingly, the wording of their operative parts is often unclear and vague. Sometimes the text of a resolution is deliberately left ambiguous so as to ensure approval by all Council members. ${ }^{318}$ The preambular paragraphs of resolutions, in turn, are often simply used to 'dump' contentious proposals and only rarely fully reflect the object and purpose of the resolution. ${ }^{319}$ Similar problems affect the resolutions that set out the terms of reference of the various sanctions committees. ${ }^{320}$ Thus, it would be crucial to have access to

\footnotetext{
315 International Law Association, Berlin Conference 2004, Final Conference Report: Accountability of International Organisations 2004, p. 8.

316 Ibid., p. 13 .

317 Wood, supra note 7, p. 82; Scharf and Dorosin, supra note 22, p. 813.

318 Talmon, supra note 9, p. 189; Wood, supra note 7, p. 82.

319 Wood, supra note 7, p. 87.

320 Conlon, supra note 47, pp. 658-659; Scharf and Dorosin, supra note 22, pp. 772, 812-815.
} 
the preparatory work of Security Council resolutions to make sense of them. The travaux préparatoires of a resolution include working papers, drafts of the resolution, and records of the discussions leading up to the resolution, especially statements made before or after the vote. ${ }^{321}$ As the ICJ pointed out in its Kosovo opinion, "[t]he interpretation of Security Council resolutions may require the Court to analyse statements by representatives of members of the Security Council made at the time of their adoption." ${ }^{322}$

However, in the case of most Security Council resolutions, such statements which could serve as useful means of interpretation will simply not be available. As explained in Section 1, the discussions leading up to a Security Council resolution mainly take place behind the scenes, in informal settings. Thus, large parts of the preparatory work are not on public record, so that the motivations of the Council members, and thus the reasons underpinning a given resolution, remain in the dark. The voting behaviour in the Security Council can only be assessed based on the hypothetical reasons that the rhetorical community assumes to be underlying it. As a consequence of this uncertainty, Council members, when confronted with criticism that their reasons are illegitimate, can simply argue that their votes were based on other than the alleged reasons.

A duty to give reasons would not only render the Security Council and its members more accountable, but would, thereby, also increase the legitimacy of the Council and of its decisions. While there are different understandings of the concept of legitimacy in international law, ${ }^{323}$ a central aspect of most of them concerns the process of decision-making, in particular with regard to qualities such as openness, transparency, representation, and participation. ${ }^{324}$ For Thomas Franck, for instance, the essence of legitimacy is "the perception of those addressed by a rule or a rule-making institution that the rule or institution has come into being and operates in accordance with generally

321 Wood, supra note 7, pp. 93-94.

322 Accordance with International Law of the Unilateral Declaration of Independence in Respect of Kosovo, 22 July 2010, International Court of Justice, Advisory Opinion, [2010] ICJ Rep p. 403 , para. 94 .

323 See Christopher A. Thomas, 'The Uses and Abuses of Legitimacy in International Law' (2014) 34 Oxford Journal of Legal Studies p. 729, for a good overview.

324 See Allen Buchanan and Robert O. Keohane, 'The Legitimacy of Global Governance Institutions' (2006) 20 Ethics and International Affairs pp. 427-429. With specific regard to the Security Council, see e.g. David D. Caron, 'The Legitimacy of the Collective Authority of the Security Council' (1993) 87 American Journal of International Law p. 561 (discussing the characteristics of the Council's decision-making process that would increase its integrity and legitimacy); Hovell, supra note 57, p. 99. 
accepted principles of right process." ${ }^{325}$ A duty to give reasons would enhance the transparency of the Security Council's decision-making process. It would allow the participants of the rhetorical community in and around the Council to be clear about the reasons for a given vote in, or decision of, the Council, to debate them, and to either let themselves be convinced by them if they find them well-founded or contest them if they find them ill-founded. Enhancing the procedural legitimacy of the Council's decision-making would, in turn, have a positive effect on compliance with its decisions. For, as has again been pointed out by Franck, the perception that a rule has come into being in accordance with the right process "exerts a pull toward compliance on those addressed normatively." 326

This is not to argue that an increase in accountability through public reason-giving is necessarily beneficial in other international contexts than the Security Council. In mediation, for example, confidentiality serves to build an environment of trust where additional information can be disclosed and parties are more willing to disclose the reasons relating to their interests. ${ }^{327}$ Confidentiality also plays an important role in international diplomacy. For the International Committee of the Red Cross ('ICRC'), for example, secrecy even forms part of its identity. ${ }^{328}$ However, decision-making in the Security Council is not comparable to the settling of bilateral disputes as in cases of mediation or to the working methods of the ICRC. States involved in mediation have no wider responsibility towards the international community. Similarly, the ICRC sees itself as accountable to victims of armed conflict, not states or the wider public. ${ }^{329}$ It therefore understands confidential dialogue with states or armed groups to be the most effective means of protecting individuals in situations in which rational discourse has been abandoned. ${ }^{330}$ The Security Council and its members, in contrast, are accountable to the whole membership of the United Nations: they act as delegates of all other UN members and can thus be

325 Thomas M. Franck, The Power of Legitimacy Among Nations (Oxford University Press, Oxford, 1990) p. 19.

326 Franck, supra note 325, p. 24.

327 Kimberlee K. Kovach, Mediation: Principles and Practice (West Publishing, St. Paul, 1994) p. 140.

328 Steven R. Ratner, 'Behind the Flag of Dunant: Secrecy and the Compliance Mission of the International Committee of the Red Cross' in Andrea Bianchi and Anne Peters (eds), Transparency in International Law (Cambridge University Press, Cambridge, 2013) pp. 297, 319.

329 Ibid., p. 316.

330 Ibid., pp. 302-304. 
characterized as "trustees of the international community". ${ }^{331}$ Improving the accountability of Security Council decisions through a duty to give reasons is, therefore, a pressing concern.

\subsection{Proposal for a Duty to Give Reasons}

\subsubsection{Introducing a Duty to Give Reasons}

The Security Council has been the subject of a multitude of reform attempts, ${ }^{332}$ many of which have aimed at changing the exercise of the veto by the Council's permanent members. The first such reform efforts were undertaken as early as in 1949 when the General Assembly adopted a resolution that asked the permanent members to "exercise the veto only when they consider the question of vital importance." 333 This recommendation, however, remained unheeded. In more recent years, there have been proposals to limit the use of the veto in R2P situations, ${ }^{334}$ to establish a duty to explain the rationale for casting a veto, ${ }^{335}$

331 Peters, Spelling Out, supra note 146, p. 314. See supra Section 2.3.1.

$33^{2}$ See Bardo Fassbender, UN Security Council Reform and the Right of Veto: A Constitutional Perspective (Kluwer Law International, The Hague, 1998) pp. 221-275, for an overview of attempts to reform the veto power and other salient features of the Council, such as its size and representativeness. See also Sabine Hassler, Reforming the UN Security Council Membership: The Illusion of Representativeness (Routledge, London, 2013).

333 UN General Assembly Resolution 267(III) (14 April 1949), UN Doc. A/RES/267(III), para. $3 \mathrm{c}$.

334 See the references in supra note 244.

335 In 1999, Germany proposed the introduction of an obligation of permanent members to explain why they are vetoing a draft resolution: UN General Assembly, $54^{\text {th }}$ Session, $8^{\text {th }}$ plenary meeting (22 September 1999), Un Doc. A/54/PV.8, p. 12. See also UN General Assembly, Report of the Open-ended Working Group on the Question of Equitable Representation on and Increase in the Membership of the Security Council and Other Matters Related to the Security Council, 55 ${ }^{\text {th }}$ Session, 2001, UN Doc. A/55/47, Supplement No 47, Annex XI (A (a)), p. 10, 16 (hereinafter Open-ended Working Group) (listing the same proposal for a duty to provide reasons for vetoes). In 2006 and 2012, the $\mathrm{s}_{5}$ suggested in a proposal for a General Assembly resolution (and in its revised version) that states should explain the reasons for resorting to a veto or declaring their intention to do so: UN General Assembly Draft Resolution (17 March 2006), UN Doc. A/6o/L.49, para. 13, and UN General Assembly Draft Resolution (15 May 2002), UN Doc. A/66/L.42/Rev.2, para. 19, respectively. In 2015, a proposal was issued by The Elders, asking that the $\mathrm{P} 5$ pledge not to use their veto in cases of genocide or other mass atrocities, "without explaining, clearly and in public, what alternative course of action they propose ... to protect the populations". These explanations, they clarify, "must refer to international peace and security, and not to the interest of the state casting the veto": The Elders, Strengthening the United Nations ( 7 February 2015), available at:<theelders.org/sites/default/files/2015-04-22_elders-statement-strengthening -the-un.pdf $>$. 
and to introduce a procedure of 'indicative voting' in the Security Council. ${ }^{336}$ All of these reform efforts have focused on the exercise of the veto by the $\mathrm{P}_{5}$. None of them has, so far, led to any changes in the Council's practice.

As opposed to this, the proposal we present in what follows imposes a duty on each member of the Security Council to explain the reasons for its vote in a public meeting. All Council members would be obliged to explain all types of votes they cast, including votes that do not qualify as vetoes. Our proposal takes account of legitimate interests that may conflict with reason-giving and is designed with a view to practical implementation. Accordingly, it allows for some flexibility: it provides for a number of exceptions to the duty to give reasons, and the extent of explanation required may differ depending on the type of decision at hand. Our proposition aims to make the procedure of reasongiving as straightforward and efficient as possible. Many votes will not require lengthy statements. Also, if a Council member agrees with the explanation given by another member, it can simply join that explanation (or parts of it). Nevertheless, the general rule will be that Council members must give reasons for their votes.

To be clear, our proposal does not require the Security Council to hold all meetings in public. It takes account of the Council's nature as a quintessentially political organ that will often have to discuss delicate political matters in informal settings. For this reason, our proposal does not prevent the Council from holding informal consultations and private meetings. Instead, it simply requires its members to explain, in a public meeting, all votes they cast.

There are three different ways of implementing a duty to give reasons as we conceive of it: first, by amending the UN Charter; second, by amending the PRoP; and third, by an informal change of practice.

First, a duty of the Council members to give reasons could be introduced by amending the UN Charter. However, any such amendment would have to be ratified by all permanent members of the Council. ${ }^{337}$ Given the lack of success of previous reform attempts that aimed at changing the composition of the Security Council or the right to veto, the prospects for the introduction of a duty to give reasons by way of an amendment of the Un Charter are dim. ${ }^{338}$ For this reason, we will not further consider this option.

336 High-level Panel Report, supra note 232, para. 257. According to the 'indicative voting' proposal, members of the Security Council should, prior to voting, give an unbinding indication of their position on a proposed action.

338 See ICIss Report, supra note 227, p. 51. 
Second, a duty to give reasons could be implemented by way of amendment of the PRoP. As opposed to the UN Charter, the PRoP can be amended without the consent of the P5. While neither Article 30 of the UN Charter (the provision concerning the rules of procedure of the Council) nor the PRoP themselves stipulate special voting requirements for amending the Council's rules of procedure, it is generally recognized that the requirement of Article 27(2) of the un Charter is applicable. ${ }^{339}$ Pursuant to this provision, Security Council decisions "on procedural matters" are to be made "by an affirmative vote of nine members". Accordingly, an amendment of the PRoP that would introduce a duty to give reasons for votes cast in the Council could not be prevented by the veto of a permanent member. In times of predominantly deadlocked Security Council reforms, changing its working methods by way of amendment of the PRoP thus constitutes a way out of the impasse. ${ }^{340}$

One could object to this way of implementing the duty to give reasons that a permanent member, when confronted with a draft for an amendment of the PRoP, would make use of the so-called 'double veto'. ${ }^{341}$ Thus, it could first raise what is called the preliminary question, ${ }^{342}$ which puts to a vote in the Council the question as to whether an issue (in our case: the amendment of the PRoP) constitutes a procedural or non-procedural matter. The permanent member could then use its veto a first time in the vote on the preliminary question, with the effect that the issue would have to be considered as a non-procedural matter according to Article 27(3) of the UN Charter, triggering the veto privilege. In the ensuing vote, it could prevent adoption of the proposal by a second use of its veto.

However, although a permanent member could not be prevented from using its double veto in such a manner, it is unlikely that it would do so as it would risk losing its face before the other Council members and the wider UN membership. For it is difficult to see how a reasonable argument could be made as to why an amendment of the PRoP should constitute a non-procedural matter in the sense of Article 27(3) rather than a procedural matter in the sense of Article 27(2) of the Charter. Neither the wording of the Charter nor that of the PRoP leave any doubt that the introduction of a duty to give reasons in the PRoP would qualify as a procedural matter: the Council adopted its rules,

339 Susanne Wasum-Rainer and Ingrid Jahn-Koch, 'Article 30' in Bruno Simma et al. (eds), The Charter of the United Nations: A Commentary ( $3^{\text {rd }}$ ed) (Oxford University Press, Oxford, 2012) p. 1028, para. 10.

340 Schweigman, supra note 75, pp. 296-297.

341 See Zimmermann, Article 27 UN Charter, supra note 175, paras. 140-141.

342 See ibid., paras. 140-154. 
entitled "Provisional Rules of Procedure", based on Article 30 of the Charter, which stipulates that the Council "shall adopt its own rules of procedure". ${ }^{343}$ Already the San Francisco Declaration of the four sponsoring governments of 1945 had made it clear that decisions made under Articles 28-32 of the Charter, which appear under the heading "Procedure", constitute procedural matters within the meaning of Article $27(2)$ and that, therefore, "the Council will, by a vote of any seven of its members, adopt or alter its rules of procedure." 344 This position has been confirmed repeatedly since then. ${ }^{345}$ Finally, the fact that, due to an informal agreement in the Council, the double veto has not been used since 1959 makes it even more unlikely that a permanent member would resort to this procedure. ${ }^{346}$

Third, a duty to give reasons could be implemented by way of an informal change of practice. Indeed, most of the recent changes in the Security Council's working methods have been achieved not by amending the UN Charter or the PRoP but by introducing new practices through informal mutual agreements among Council members. ${ }^{347}$ Such mutually agreed changes may later be 'formalized' through Statements or Notes by the President of the Security Council or, more rarely, resolutions of the Council. ${ }^{348}$

There are advantages and disadvantages to both the formal way of introducing a duty to give reasons by way of an amendment of the PRoP and the informal way through a change of practice. A formal amendment of the PRoP would be more transparent, and the Council members would most likely regard the duty as more binding. In contrast, an informal change would allow

\footnotetext{
343 Emphasis added.

344 Statement by the Delegations of the Four Sponsoring Governments on 'The Yalta Formula' on Voting in the Security Council (8 June 1945), UNCIO Vol XI, 710, para. I.2., reprinted in Bailey and Daws, supra note 28, p. $45^{6}$.

345 See Zimmermann, Article 27 UN Charter, supra note 175, paras. 90-93; Report of the Interim Committee of the General Assembly on the Problem of Voting in the Security Council (15 July 1948), un Doc. A/578, p. 201. See also Report of the Open-ended Working Group, $57^{\text {th }}$ Session (2003), UN Doc. A/57/47, Supplement No 47, Annex IV, p. 13 (confirming that the veto should be excluded in procedural matters).

346 See Zimmermann, Article 27 UN Charter, supra note 175, para. 159; Repertoire of the Practice of the Security Council, $17^{\text {th }}$ Supplement 2010-2011, Part II, Provisional Rules of Procedure, 2011, p. 66 ('Repertoire of the Practice of the Security Council, 2010-2011'). See also Repertoire of the Practice of the Security Council $16^{\text {th }}$ Supplement 2008-2009, Part II Provisional Rules of Procedure, 2009, p. 320 (confirming that in recent years, the Council has not examined the preliminary question).

347 Wood, supra note 6, p. 159.

348 Volger, supra note 11, p. 196.
} 
the Council and its members to retain more flexibility, which increases the prospects for adoption. Although we do not favour one way of implementation over the other, we will-for the sake of illustration - put forth a concrete proposal for a formal amendment of the PRoP in order to demonstrate how a provision introducing a duty to give reasons for votes cast in the Security Council could be worded. In our opinion, Rule 48 of the PRoP, which opens Chapter IX entitled "Publicity of Meetings, Records", seems particularly well suited to accommodate a duty to give reasons. Our proposition can serve as a guideline, regardless of whether the duty to give reasons is endorsed formally or informally. Also in the latter case, that is, if the Council members agree on a change of practice rather than a formal amendment of the PRoP, our proposal can function as an inspiration as to the content of such an informal change.

We suggest to add a new second paragraph to Rule 48, with the following wording:

Rule 48

Unless it decides otherwise, the Security Council shall meet in public.

Each Member of the Security Council shall provide the reasons for its vote in the public meeting. A Member may upon request be relieved by the President from its duty to give reasons if it demonstrates that there is a risk that disclosure of the respective information would cause harm to legitimate privacy or security interests. The President shall grant the exemption provided that information is only withheld to the degree necessary to protect the respective interest and that the possible harm caused by disclosure of the relevant information to the protected interest outweighs the interest in disclosure.

Any recommendation to the General Assembly regarding the appointment of the Secretary-General shall be discussed and decided at a private meeting.

4.2.2 "Each Member of the Security Council ..."

A first issue that must be clarified is to whom exactly the duty to give reasons applies. Is it incumbent on each member of the Security Council or rather on the Council as a whole? As demonstrated in Section 4.1.2, there are a number of different rationales supporting the introduction of a duty to give reasons for the voting behaviour in the Security Council: reason-giving increases the quality of the adopted decisions, enhances legal certainty, and allows the Security Council and its members to be held accountable. Depending on the 
importance one attaches to these different rationales, the duty to give reasons will apply to different entities. For instance, if the accountability of the Security Council (or one of its committees) as a collective body is given the greatest weight, then a statement of reasons issued by the Council (or the respective committee) itself might be the best means of allowing those affected by its decisions to challenge them. This explains, for example, why the ${ }_{12} 67$ Committee has been obliged to publish a joint 'narrative summary of reasons' for listing individuals on the sanctions list. ${ }^{349}$ This narrative summary allows individuals to substantiate their requests for delisting by challenging a consolidated set of reasons that has led to their listing, rather than having to find these reasons in separate statements of the Committee's members. On the other hand, if the quality of votes (and, thereby, of the decisions to which they contribute) is given more importance, then individual statements of reasons by each Council member are preferable, since states are more likely to adopt reasonable decisions if they have to persuade other actors of their respective reasons. Since the main concern of our proposal is to force Council members to engage in a rational discourse, we suggest - at least with regard to decisions of the Council itself (as opposed to those of its subsidiary bodies) - the following solution: instead of a duty incumbent on the Council as a collective body, each Council member should be obliged to provide the reasons for its vote.

For the same reason, unlike the better part of previous reform proposals, ${ }^{350}$ the duty to give reasons we propose is not restricted to the permanent members but extends to all members of the Security Council. The reason for this is simple: despite the fact that the veto privilege accords the $\mathrm{P} 5$ significant voting power, they are not the only members with the capacity to prevent a decision in the Council. Pursuant to Article 27(3) of the UN Charter, the vote of at least seven non-permanent members has the same effect as the veto of one permanent member. Therefore, it would be inconsistent to impose a duty to give reasons only on the $\mathrm{P} 5$. In order to set in motion the process of the civilizing force of hypocrisy and to ensure that individual Council members can be held accountable for their voting behaviour, it is necessary to oblige all members to give reasons for their votes. ${ }^{351}$ Even with regard to votes of non-permanent

\footnotetext{
349 See supra note 218.

350 See e.g. Peters, Spelling Out, supra note 146, pp. 323-324 (proposing a duty to give reasons that is limited to the P5). See also the proposals listed in supra note 335, which all concentrate on the $\mathrm{P} 5$.

$35^{1}$ See also Fassbender, supra note 332, p. 328 (arguing that the logic of the proposal that permanent members should only exercise the veto in questions of vital importance also applies to non-permanent members).
} 
members that do not gather the necessary majority to prevent a decision of the Security Council, a duty to give reasons serves a useful purpose as it enables the rhetorical community to assess the reasons underlying these votes.

To draw an analogy, if the Security Council was to be compared to a court, our proposal could be said to follow the approach prevalent in common law systems (where, in general, every judge delivers her or his own opinion), rather than in civil law systems (where, in general, the court gives reasons for its judgment as a collective body). This 'common law approach' ensures that the individual members of the Council cannot hide behind the explanation given by the majority while still maintaining their self-interested justifications when voting. By requiring every member to explain its reasons independently, the discursive effects referred to in Section 4.1.2 can come into play for each member. In addition, our 'common law proposal' is also more practicable than a joint statement of reasons by the Security Council as a whole. Our proposal does not require that the Council members agree on a certain justification for a decision. Also, it obviates the need for a secretary or a clerk in charge of drafting joint statements of reasons for decisions.

For subsidiary bodies of the Security Council tasked with adopting measures that directly affect individuals, on the other hand, the 'civil law model' may be preferable. In these cases, the main concern is to provide for an effective accountability mechanism with regard to the decisions of the subsidiary body itself, an aim which may be better served through the provision of a joint statement of reasons.

\subsection{3 "... shall provide the reasons ..."}

Another aspect of our proposals that must be spelled out is the extent of reasons that each member of the Security Council has to provide in a public meeting to explain its votes. We argue that the extent depends on the following variables: the type of decision at hand (procedural or non-procedural; executive, administrative, or legislative $)^{352}$ and the type of Security Council member concerned (permanent or non-permanent).

With regard to the type of decision at hand, the extent of the reasons that need to be given depends, first, on whether a procedural or non-procedural matter is voted on. In the case of matters that are clearly procedural, the requirements regarding reason-giving will in general be relaxed. In many cases,

352 See also Robin John Feakins v. The Scottish Ministers, 19 June 2014, European Court of Justice, Opinion of Advocate General Kokott, Case C-335/13, 2014, para. 64 (arguing that "the scope of the obligation to state reasons depends on the nature of the legal act in question"). 
these matters are of such minor significance that an explanation will not be required at all. This is in line with the current practice of the Security Council, which in cases of "procedural motions such as the adoption of the agenda, the extension of invitations, and the suspension or adjournment of a meeting"353 has even dispensed voting altogether. However, situations might arise in which also votes on procedural matters can be of greater significance. For example, the establishment of a new body or agency that assists the Security Council in fulfilling its functions, can-depending on the nature of this body-have rather far-reaching implications. In such a case, the extent of reasons provided will need to be more elaborate.

Second, the extent of reasons depends on whether an executive, administrative, or legislative-type decision is at hand. As we have indicated above, the Security Council has considerably broadened its scope of activity over the last 25 years and has started to adopt - in addition to decisions that can be qualified as executive - an increasing number of decisions that are of a legislative or administrative nature. ${ }^{354}$ As a general rule, decisions that directly affect individuals, which are typically adopted by the Security Council's subsidiary bodies, 355 need to be supported by detailed reasons. ${ }^{356}$ Explanations must be such as to enable the individual to identify and understand the reasons that have led to the decision. On the other hand, the requirements with regard to the degree of reasons are less strict if decisions only have an indirect impact on individuals, as is the case with general and abstract Security Council decisions. ${ }^{357}$ Thus, the more direct and important the impact on individuals is, the higher the requirements concerning the extent of reasons are. Whereas in some situations a single sentence might suffice in order to comply with the duty, a more elaborate justification is needed in others.

In the case of executive-type decisions, that is, decisions within the scope of the traditional crisis management role of the Security Council, the Council possesses large discretion. This especially holds true for the determination according to Article 39 of the Charter concerning the existence of a threat to the peace, a breach of the peace, or an act of aggression. In addition, since the

353 Repertoire of the Practice of the Security Council, 2010-2011, supra note 342, p. 66.

354 See supra Section 1.1.

355 See supra Section 1.2.

356 Antonios Tzanakopoulos, 'Transparency in the Security Council' in Andrea Bianchi and Anne Peters (eds), Transparency in International Law (Cambridge University Press, Cambridge, 2013) pp. 389-39o.

357 See for an analogous rule in the law of the European Union: Heinz Hetmeier, 'Art 296 AEUV' in Carl Otto Lenz and Klaus-Dieter Borchardt (eds), EU-Verträge Kommentar, EUV, $A E U V, G R C H\left(6^{\text {th }}\right.$ ed) (Bundesanzeiger Verlag, Köln, 2012) p. 2866, para. 8. 
Council needs to be able to take "prompt and effective action"358 with regard to the maintenance of international peace and security, there is normally no time for extensive deliberation. ${ }^{359}$ Accordingly, the requirements for the explanation of votes on such decisions are reduced. Yet also executive-type decisions demand a minimal extent of reasons to allow for their assessment by the rhetorical community. This is especially the case for resolutions adopted under Chapter vir that touch on matters of major political importance.

As regards administrative-type decisions, that is, decisions that are aimed at and directly affect specific individuals, groups, or corporate entities, the duty to give reasons is particularly important as it is an indispensable prerequisite of accountability. Thus, we have argued in Section 3.1 above that, at least with regard to some of these decisions, international human rights law imposes already today, de lege lata, an obligation on the Security Council to give reasons and, respectively, on its members to explain their votes in the Council. As far as the Council has established international criminal tribunals for the prosecution of certain individuals, it has discharged this obligation by transposing it on these tribunals. In contrast, the Council has not imposed a corresponding duty to give reasons on its sanctions committees, even though they are authorized to impose measures such as travel bans, assets freezes, and arms embargoes on specific individuals and non-state entities. When the Council (or one of its subsidiary bodies) adopts decisions that directly affect important interests of non-state actors, they must be informed about the reasons for the decision or, in the case of the sanctions committees, about the basis for the listing. The explanations must be detailed enough to allow those affected to understand whether their arguments have been properly examined and, if necessary, to enable them to challenge the decision.

Concerning legislative-type decisions, finally, a more nuanced view is necessary. The defining characteristic of legislative resolutions is that they impose obligations of a general and abstract nature, that is, obligations that are addressed to all states and that are not restricted to a particular situation. ${ }^{360}$ Accordingly, they do not normally affect individuals, at least not directly. ${ }^{361}$ In line with the general rule stated above, when voting on such decisions,

$35^{8}$ UN Charter, Art 24(1).

359 See Johnstone, supra note 9, p. 276.

36o Cathleen Powell, 'The Legal Authority of the United Nations Security Council' in Benjamin J. Goold and Liora Lazarus (eds), Security and Human Rights (Hart Publishing, Oxford, 2007) pp. 166-167; Talmon, supra note 9, p. 176.

361 See Keith Harper, 'Does the United Nations Security Council Have the Competence to Act as Court and Legislature?' (1994) 27 New York University Journal of International Law and Politics pp. 126-127. 
Council members would therefore not need to provide elaborate reasons. Nevertheless, there are important arguments in favour of providing robust reasons also for legislative-type decisions. ${ }^{362}$ Despite their general character, they often affect individuals indirectly, as is the case, for example, with the counterterrorism measures that states are required to adopt under Resolution 1373. What is more, legislative acts of the Council typically have far-reaching consequences, not only because they are directed at all states but also because they are concerned with issues of major political importance. ${ }^{363}$ This is why it is crucial to get Council members to engage in an open exchange of rational arguments that can be assessed by the broader rhetorical community, not least to ensure the broad cooperation that implementation of legislative resolutions requires. ${ }^{364}$ As compared to executive-type decisions, legislative decisions will in general necessitate more detailed reasons because they directly concern all states and are more likely to indirectly affect individuals. Unlike administrative decisions, which must be supported by specific reasons allowing those who are directly affected to challenge them, however, it will suffice for Council members to provide general reasons corresponding to the general and abstract character of the obligations imposed by legislative decisions. ${ }^{365}$

Furthermore, the extent of reasons required depends on the type of Security Council member that casts its vote. In particular, permanent members will in general face different requirements than non-permanent members. Although both non-permanent and permanent members can prevent decisions, only the latter have the power to veto a decision on their own. As we pointed out in Section 3.2 regarding the de lege lata duty to give reasons under the R2P, since the $\mathrm{P} 5$ are in a more powerful position, they must bear stricter obligations. Indeed, the very fact that these particular states were given the veto power in the UN Charter was justified with the greater responsibilities that are incumbent on them. ${ }^{366}$ For this reason, the $\mathrm{P} 5$ will in general have to provide more detailed reasons for their votes in the Security Council than non-permanent members.

\footnotetext{
362 See Hetmeier, supra note 357, p. 2863 , para. 4.

363 See Talmon, supra note 9, pp. 186-187.

364 See Johnstone, supra note 9, p. 275.

365 See International Law Association, supra note 316, p. 13 ("With regard to decisions of a general nature, the reasons may relate to the general character of such a decision only."). For the context of TfEu, Art 296(2), see Robin John Feakins v. The Scottish Ministers, 19 June 2014, European Court of Justice, Opinion of Advocate General Kokott, Case C-335/13, 2014, para. 64 ("In the case of measures of general application, the statement of reasons may be confined to indicating the general situation which led to the adoption of the measure and the general objectives which it is intended to achieve.").
}

366 Rudolf Geiger, 'Article 23' in Bruno Simma et al. (eds), The Charter of the United Nations: A Commentary ( $3^{\text {rd }}$ ed) (Oxford University Press, Oxford, 2012) p. 751, para. 10. 
Nevertheless, in a situation in which adoption of a decision is prevented not by the $\mathrm{P}_{5}$, but seven or more non-permanent members, the latter will have to explain in more detail what their motivations for doing so are.

\subsection{4 "... for its vote ..."}

We do not only propose that each member of the Security Council must provide reasons for its votes, but - again in contrast to other reform proposalsthe duty suggested by us is also not limited to 'no' votes. The rationales for knowing the reasons behind a given vote apply equally to negative and affirmative votes. The reason for this is that not only a vote against a draft resolution of the Security Council can be considered illegal because, for example, it precludes the Council from preventing massive human rights violations. Also an affirmative vote of a member (or its abstention) can be incompatible with international law. ${ }^{367}$ Take, for example, a draft resolution that aims at establishing a sanctions regime that violates human rights. An affirmative vote on such a resolution by a Council member may be illegal. Yet the rhetorical community will only be able to assess the voting behaviour in such a scenario if the duty to give reasons extends to affirmative votes of Council members. Therefore, we propose a duty to give reasons for both negative and affirmative votes.

\subsection{5 "... harm to legitimate privacy or security interests ..."}

In order for our proposal for a duty to give reasons to be a workable mechanism, it must not only be flexible with regard to the extent of reasons that may be required but also allow for certain exceptions that protect Council members from having to disclose sensitive information. We suggest that there are two kinds of interests that may justify non-disclosure: privacy interests and security interests. According to our proposal, reasons relating to these types of interests would not have to be disclosed in a public meeting as long as non-disclosure is necessary and balanced. These exceptions allow Council members to efficiently perform their responsibilities under the UN Charter, while still providing reasons for their votes as far as possible.

Firstly, members of the Council (or of one of its subsidiary bodies) do not have to (and indeed must not) disclose in a public meeting information if this would violate the privacy of any affected person. Such sensitive information includes, for example, bank accounts, addresses, or medical records of persons who are to be placed on a sanctions list.

An exception from the duty to give reason must, secondly, apply where the relevant information is related to security interests and where there is a

$367 \quad$ See supra Section 2.3.2. 
risk that disclosure would cause some degree of harm to these interests. ${ }^{368}$ A general invocation of security, however, is not sufficient. Instead, a specific and identifiable threat to security interests must be shown. ${ }^{369}$ For example, strategic information with regard to the armament and location of military forces that is important to the success of an operation authorized by the Council would not have to be disclosed. This exception is supported by the fact that also under most domestic legal systems, security issues are regularly exempted from disclosure requirements. ${ }^{370}$ The Security Council, whose primary responsibility it is to maintain peace and security on the international level, should therefore a fortiori benefit from a respective exemption.

\subsection{6 "The President shall grant the exemption ..."}

Exemptions based on legitimate privacy and security interests are only practicable if there is a body that can decide on giving or refusing them. We believe that the President of the Security Council is the most suitable body for exercising this task because it is the President who is entrusted by the PRoP with all formal tasks in the Security Council. Among these tasks are, for example, those of calling meetings (Rules 1-3), approving the agenda (Rule 7), presiding over the meetings (Rule 19), overseeing the conduct of business during meetings (Rules 27-39), and deciding on the importance of corrections to meeting records (Rule 52). Because the presidency is held in turns and each President only holds office for one month, the risk of lopsided and biased exemptions is reduced.

According to our proposal, Council members can submit an exemption request to the President before the relevant public Council meeting, setting out that there is a risk that the disclosure of specific information would cause harm to legitimate privacy or security interests. When receiving an exemption request, the President will have to undertake a two-stage assessment that bears analogy to the two-stage analysis that is applied for human rights limitations. ${ }^{371}$ At the first stage, the President needs to verify whether the requesting Council member indeed possesses a legitimate privacy or security interest

368 See Hovell, supra note 57, p. 106. This exception is also recognized by the ECJ: HTTS Hanseatic Trade Trust and Shipping GmbH v. Council, 7 December 2011, European Court of Justice, Case T-562/10, para. 33 .

369 Hovell, supra note 57, p. 106.

370 Ibid., pp. 97, 105.

371 See Aharon Barak, 'Proportionality (2)' in Michel Rosenfeld and Andras Sajo (eds), The Oxford Handbook of Comparative Constitutional Law (Oxford University Press, Oxford, 2012) pp. 738, 740 . 
with regard to the matter at hand. At the second stage, the President first has to analyse whether the Council member suggests withholding information to the degree necessary to protect the respective interest (that is, a least restrictive means test). The President has to make sure that only information relating to the sensible aspects of a matter will be withheld. Consider the example of Security Council Resolution $1973,{ }^{372}$ which authorized UN member states to take all necessary measures to protect Libyan civilians and establish a no-fly zone in the Libyan airspace. With regard to this resolution, a Council member would have been justified in withholding information, disclosure of which could have jeopardized the security and the success of the military operation. Disclosure of such information could have resulted in a considerable degree of harm, especially to the rebels. There were other parts of the resolution, however, with regard to which the Council members probably could not have been exempted from providing reasons, including the parts regarding the arms embargo (paras 13-16), the ban on flights (paras 17-18), and the Panel of Experts (paras 24-29). After determining whether withholding certain information is necessary, the President then has to engage in balancing the relevant interests. In particular, the President has to decide whether the possible harm caused by disclosure outweighs the conflicting interest in disclosing the information. Only if withholding the information at issue is both necessary and balanced can (and indeed must) the President grant the exemption.

In summary, our proposal for a duty to give reasons applies to each member of the Security Council and for all types of votes. An exemption from this duty is only possible upon request to the President of the Security Council. The President will grant the request if the Council member demonstrates that disclosure of the respective information would cause harm to legitimate privacy or security interests, that the information is only withheld to the degree necessary to protect that interest, and that the possible harm caused by disclosure outweighs the interest in disclosure.

\section{5 \\ Conclusion}

On 27 March 2013, on the occasion of the inauguration of the newly renovated Consultations Room - the chamber adjacent to the Security Council Chamber built in 1978 for holding informal consultations - the representative of the Russian Federation (and then Security Council President) remarked:

372 UN Security Council Resolution 1973 (17 March 2011), UN Doc. s/REs/1973. 
This is the place where most important decisions affecting international peace and security are hashed out. This is the place where most heated debates occur. This is the place where the diplomats who have the privilege to work in the Security Council spend the most interesting hours and days of their professional lives. This is, quite simply, the most fascinating place in the entire diplomatic universe. ${ }^{373}$

That the most heated debates on issues affecting international peace and security would be held in secret outside the Security Council's actual meeting place is not what states had in mind when they drafted the UN Charter and the PRoP. They expected these debates to take place in the formal, public meetings of the Council, not behind closed doors. They thought that these meetings would serve as a forum in which the members of the Council would explain their respective positions. ${ }^{374}$ However, due to the shift of decision-making from the Security Council Chamber to the Consultations Room, from public to informal meetings, the public meetings have been deprived of their original function. As the public meetings have been reduced to mere pro forma affairs, it has become difficult for the rhetorical community in and around the Security Council to understand the motives behind a given resolution.

Seen from this perspective, our proposal for a duty to give reasons for votes cast in the Security Council is by no means revolutionary: all it aims to achieve is to restore the function of the public meetings as it was originally conceived and to force the explanation of positions back into the public sphere. Council members would still be permitted to negotiate in informal settings, but they would have to explain the reasons for their votes in a public meeting. This would improve legal certainty regarding the Council's decisions and enhance the accountability (and thus also legitimacy) of the Council and its members. Most crucially, however, it would lead to qualitatively better decisions. The substance of a debate is shaped to a very considerable degree by its public or secret nature. States are acutely aware of this fact. When, for example, the

373 Inauguration of the Russian Room (Security Council Consultations Room), Remarks by H.E. Mr. Vitaly I. Churkin, 27 March 2013, available at: <webtv.un.org/search/inauguration -of-the-russian-room-security-council-consultations-room/2258040243001?term=consult ationsandlanguages=Englishandsort $=$ date $>$ (at 02:30 minutes).

374 See Section 1.1 (demonstrating that in the early years of the UN, public meetings were the rule). That public meetings were originally conceived as the primary locus for Council debates also becomes evident when considering PRoP, Rule 48. The wording of this rule, adopted in 1946, makes it clear that, apart from rare exceptions, the Council was supposed to meet in public; see also Reid, supra note 27 . 
Security Council was to hold a special session on the Ukraine crisis, a dispute arose among its members as to the format of the session. While Russia wanted an informal consultation behind closed doors, the other Council members insisted on a public meeting. ${ }^{375}$ States would be more reluctant to block Security Council action designed to prevent serious violations of international law if they were forced to explain in public their reasons for doing so.

Requiring the members of the Security Council to give reasons for their voting behaviour accords with the very structure of the international legal system. The Council members act as trustees of the international community. The international community must know what positions they stand for.

375 Louis Charbonneau, Western Nations Line Up at UN to Slam Russia's Moves on Ukraine, Reuters, 3 April 2014, available at: <www.reuters.com/article/2014/04/14/us-ukraine-crisis -un-idUSBREA32Do3J20140414>. 